\title{
Tomato Fruit Marketability, Blossom-End Rot Incidence and Quality as Affected by Different Calcium Sources and Time of Application Under Calcareous Soil \\ El-Tantawy, E. M. and M.I. Mahmoud \\ *Plant Production Department (Vegetables), Faculty of Environmental Agricultural Sciences, EL-Arish University, Egypt.
}

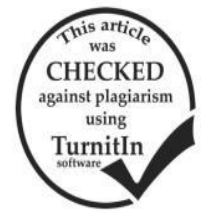

\begin{abstract}
Two field experiments were carried out during the winter seasons of 2011/2012 and 2012/ 2013 at The Experimental Farm of The Faculty of Environmental Agricultural Sciences, El-Arish, Suez Canal University, North Sinai Governorate, Egypt. The experiment aimed to study the effect of spraying tomato plants (Solanum lycopersicum) GS $12 \mathrm{cv}$. with different calcium sources (calcium chloride, calcium carbonate and calcium chelate as well as without calcium) at different times of application, viz, $T_{1}$ : spraying one time at full blooming, $T_{2}$ : spraying one time after 15 days from $T_{1}$, and $T_{3}$ : spraying two times at $T_{1}+T_{2}$ on marketable yield, unmarketable yield (expressed as fruits infected by blossom end rot (BER)), and quality of fruits after 10 days of beginning the storage period. Plants were grown under low tunnels. Spraying tomato plants with $\mathrm{Ca}^{+}{ }^{2} \mathrm{CaCl}_{2}$ or $\mathrm{CaCO}_{3}$ and other Ca sources increased the marketable yield/ fed. , and also increased fruit shelf life period expressed as decreasing in fruit weight loss and increasing fruit firmness. Foliar application of $\mathrm{CaCl}_{2}$ recorded the lowest values of lycopene contents in both seasons. Time of calcium application did not reflect any significant effect on both marketable and nonmarketable yield as well as marketability (\%) and BER incidence (\%), and almost pH and TSS values. Application of T3 increased the fruit contents of vitamin C (V.C), while using T2 decreased the content of lycopene. All interaction treatments with control (without application of calcium) decreased marketable yield, marketability (\%), but it increased unmarketable yield, BER incidence (\%), fruit weight loss and TSS in the $2^{\text {nd }}$ season. Therfore, spraying tomato plants grown under low tunnels in calcareous soil with Ca in different sources had positive effects on both marketable yield and blossom-end rot incidence, total yield, marketability $\%$, BER\% and on fruit quality after 10 days of storage period compared to control.
\end{abstract}

Keywords: Tomato, calcium sources, application time, marketable yield, BER, fruit quality

\section{INTRODUCTION}

Tomato (Solanum lycopersicum) is one of the major and important vegetable crop in Egypt which consumed in fresh or proccess forms. Tomato fruits contain some important nutritional compunds for human health such as phenolic, vitamins and lycopene which helps counteract the harmful effects of free radical and increase the body defense against several disease and number of cancers, especially prostate cancer and cardiovascular disease (Barber and Barber, 2002; Khan et al., 2006; Pila et al., 2010).

Calcium plays very important roles as an essential nutrient necessary for plant growth. It is essential for various processes, such as the maintenance of the plant cell structure, resistance to environmental stresses (salinity, drought, chilling, heat, etc.), and most important, as a secondary messenger in signal transduction in plants (Mestre et al., 2012). In this connection, many efforts were done to study the effect of calcium on tomato (fruit yield, marketability and storability), and most of invisitigators found a possetive effect in this regard. Application of calcium enhance plant growth and tomato fruit yield and increased the resistance of tomato to fungal disease (AghofackNguemezi and Tachago, 2010; Mestre et al., 2012; Aghofack-Nguemezi et al., 2014). Application of Ca (as $\mathrm{CaCl}_{2}$ ) increased number of fruits / plant and yield/ha.(Ilyas et al., 2014). Spraying tomato plants with Ca-chelate increased total and marketable yield/fed. (Elbeik, 2014). Also it had no significant effect on fruit yield/ fed. (Rab and Haq, 2012). Fruits deformed (BER) occurs mostly during a period of high cellular $\mathrm{Ca}$ demand when growth of fruits is accelerated or $\mathrm{Ca}$ dilivery to the fruits is limited (Bradfield and Guttridge, 1984; Ho, 1989; Marcelis and Ho, 1999). So, addition of $\mathrm{Ca}$ during the period of rapid vegetative growth and fruit setting is very important to overcome fruit deformation due to Ca defficiency. The marketability of honey dew fruits were increased when plants sprayed four tims by Ca (Lester and Grusak, 2004), but it did not affect on cantaloup BER, while it did not affect total marketable fruit yield and number of deformed fruits (Lewandowski, 2003).

Blossom- end rot (BER) is the most common physiological disorder found in tomato and pepper. It may occur in all the tomato-producing areas of the world and has been shown to create losses of up to $50 \%$ of production (Casado-Vela et al., 2005). Many investigators found a correlation between the occurrence of BER and Ca nutrition. Byeon, et al. (2012) found that application of calcium led to supressed the incidence of BER in pepper which decreased from $62.6 \%$ to $19.2 \%$. De Freitas and Mitcham (2012) supported the hypothesis that BER is not only related but caused by fruit calcium defficiency. In addition, Nonami et al., (1995) suggested that Ca defficiency in the fruit may not be the direct cause of the occurrence of BER in tomato, because fruit that had just started having BER had a similar distribution and concentration of $\mathrm{Ca}$ ion as normal fruit. Saure (2014) in a reappraisal concluded that the actual causes of BER are obeviousely the effect of a biotic stress, as salinity, drought, heat, increase in reactive oxygen species (ROS) . Exogenous application of calcium can improve plant growth under 
evironmental stress (Tuna et al., 2007). Moreover, application of $\mathrm{Ca}$ in high concentrations regardless the source can reduce the fruits infected by BER (Mestre et al., 2012; Rab and Haq, 2012; Ilyas et al., 2014).

Because tomato is highly perishable, nearly 30$50 \%$ of the production is lost after harvest due to inadequate handling and preservation (Inaba and Crandall, 1986). In the mature treated tomato fruits with calcium could bind with carboxylic groups in pectin to form cross bridges in the cell wall and membrane complexes (Leshem, 1991; Magee et al., 2003). This proess reinforce the rigidity of the cell wall (Leshem, 1991). Thus these cross bridges significantly prolong the green-life of mature fruits. Even though some efforts were done to minimize the postharvest losse, enhance the shelf life, delay ripening and improve or maintain the colour and quality such as application of calcium chloride. In this connection, Lester and Grusak (2004) found that spraying honey dew plants four times by calcium increased fruit firmness and decreased fruit weight loss (Bhattarai and Gautam, 2006; AghofackNguemezi and Tachago, 2010; Pila et al.,2010). Application of $6 \% \mathrm{CaCl}_{2}$ increased tomato fruits shelf life, firmness, delay in fruit colour development, reduced ethylene production, but $\mathrm{pH}$, TSS and TA\% were not significantly affected (Senevirathna and Daundasekera, 2010). It could be said that $\mathrm{Ca}$ foliar application possitively affected tomato fruit production, and it is very important to overcome Ca defficienc.

So, the aim of this work was to study the effect of supplying tomato plants with calcium in different sources and application times at rapid growth period under calcareous soil on yield and fruits quality after storage period.

\section{MATERIALS AND METHODS}

A field experiment was carried out under low plastic tunnels during the winter seasons of 2011/2012 and 2012/ 2013 at The Experimental Farm of The Faculty of Environmental Agricultural Sciences, ElArish, Suez Canal University, North Sinai Governorate, Egypt. The main objective of this research was to study the effect of spraying tomato plants (Solanum lycopersicum) $c v$. GS 12 with four calcium sources (calcium chloride $\left(\mathrm{CaCl}_{2}\right)$, calcium carbonate $\left(\mathrm{CaCO}_{3}\right)$, calcium chelate as well as control (without calcium) at three different times of application $\left(\mathrm{T}_{1}\right.$ : once at full bloom, $\mathrm{T}_{2}$ : once after 15 days from $\mathrm{T}_{1}, \mathrm{~T}_{3}$ twice at $\mathrm{T}_{1}$ and $\mathrm{T}_{2}$ ) on yield and quality of fruits.

This experiment included 12 treatments, which were the combinations between the four calcium sources and the three times of applications. The treatments were randomly arranged in a split plot design in a randomized complete block design with three replications. Calcium sources treatments were randomly arranged in the main plots and time of applications were randomly distributed in the sub - plots. Plants were foliar sprayed with a concentration of $2 \%$ from each calcium source (with $1 \mathrm{ml} / 1$ Tween 20 as spreading agent). The untreated control plants were sprayed with tap water and spreading agent. Treatments were incepted at full bloom stage (40 days after transplanting). Plot area was $45 \mathrm{~m}^{2}$, which consists of 3 double dripper lines $10 \mathrm{~m}$ in length and $1.5 \mathrm{~m}$ in width. Tomato seedlings were transplanted on $25^{\text {th }}$ and $29^{\text {th }}$ December in the $1^{\text {st }}$ and $2^{\text {nd }}$ seasons, respectively. The distance between each two plants was $50 \mathrm{~cm}$.

The physical and chemical properties of experimental soil profile from $0-30 \mathrm{~cm}$ of soil surface are shown in Table 1.

Table 1: Initial of some physical and chemical properties of investigated soil profile of cultivated area and irrigation water

\begin{tabular}{|c|c|c|}
\hline Properties & Season 2011/2012 & Season 2012/2013 \\
\hline \multicolumn{3}{|l|}{ Soil properties } \\
\hline Soil texture class & Loamy sand & Loamy sand \\
\hline \multicolumn{3}{|l|}{ Soil chemical properties } \\
\hline Organic matter $\%$ & 0.170 & 0.180 \\
\hline 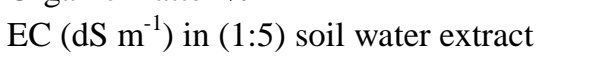 & 1.32 & 1.45 \\
\hline $\mathrm{pH}$ in $(1: 2.5)$ soil water suspension extract & 8.2 & 8.00 \\
\hline $\mathrm{Cl}^{-}(\mathrm{meq} / \mathrm{l})$ & 5.36 & 6.48 \\
\hline $\mathrm{CaCO}_{3} \%$ & 16.21 & 15.56 \\
\hline Available N $\quad$ (ppm) & 15.31 & 14.88 \\
\hline Available $\mathrm{P} \quad(\mathrm{ppm})$ & 46.11 & 44.17 \\
\hline Available K (ppm) & 92.88 & 94.15 \\
\hline \multicolumn{3}{|l|}{ Analyses of irrigation water } \\
\hline $\left.\mathrm{EC}(\mathrm{dS} \mathrm{m})^{-1}\right)$ & 6.12 & 6.74 \\
\hline $\mathrm{pH}$ & 7.59 & 7.64 \\
\hline $\mathrm{Cl}^{-}(\mathrm{meq} / \mathrm{l})$ & 47.04 & 48.46 \\
\hline
\end{tabular}

All experimental units received compost at a rate of 4 tons/ fed. added in the center of rows (recommended dose). The source of compost was Al-
Arabiah for organic fertilizer factory, Sharkia Governorate, Egypt. The physical and chemical properties of compost were as follows: $1.24 \%, 1.5 \%$ 
total $\mathrm{N}, 0.58 \%, 0.38 \%$ total $\mathrm{P}, 1.15 \%, 0.63 \%$ total $\mathrm{K}$, $36.56 \%, 35.3 \%$ organic matter, $\mathrm{pH}(1: 10) 8.1,8.4$ and $\mathrm{C} / \mathrm{N}$ ratio $1: 17,1: 14$ in the first and second seasons, respectively. Tomato plants received the recommended dose of NPK $\left(124 \mathrm{~kg} \mathrm{~N}, 86 \mathrm{~kg} \mathrm{P}_{2} \mathrm{O}_{5}\right.$ and $144 \mathrm{~kg} \mathrm{k} \mathrm{K}_{2}$ /fed.). One third of fertilizers quantity were added during soil preparation and the other two - thirds were divided into twenty portions and added gradually (two times weekly) through the irrigation water beginning eight days after transplanting. The other conventional practices were applied.

\section{Data Recorded:}

\section{Yield and Its Components:}

At red maturity stage, fruits of each plot were harvested, counted and weighed, and the following data were recorded:

-Marketable yield: all fruits at harvest stage within all harvest times were collected, counted, weighed and number of fruits/plant (gm) as well as yield/fed. (ton) were calculated.

-Unmarketable yield: yield/fed. (ton) was measured (expressed as infected fruits with blossom-end rot).

- Marketability (\%): \{(marketable yield (ton/fed.) / total yield) (marketable + unmarketable yield (ton/fed.)) $\}$ x 100.

- BER incidence (\%): \{(unmarketable yield (ton/fed.) / total yield) (marketable + unmarketable yield (ton/ fed.)) $\}$ x 100 .

II. V.C.: It was determined in tomato fruits from the second harvest according (A.O.A.C., 1975).

\section{Storability of fruits:}

Sample of fruits $(30$ fruits $)$ from each experimental unit of the second harvest at red stage, free visually from disease and defects were randomly taken and directly transformed to the lab. Fruits were stored at room temperature (average 22.8, $23.3^{\circ} \mathrm{C}$ and 62.1, 62.7 $\% \mathrm{RH}$, in $1^{\text {st }}$ and $2^{\text {nd }}$ seasons, respectively). Storage period of fruits were started from $1^{\text {st }}$ to $10^{\text {th }}$ April, and the following physical and chemical parameters were measured:

A- Physical parameters: were determined twice with period 10 days between them as follows:

- Fruit weight loss (gm): It was determined as the subtraction between the first and second sample fruit weight.

- Firmness $\left(\mathbf{k g ~} / \mathrm{cm}^{2}\right)$ : It was measured using a manual penetrometer (Model st 207) as average of three reading for each treatment.

- Decreasing rate in hardness: It was determined as the subtraction between the first and second reading.

B- Fruit quality: was determined twice as appearance measurements as follows:

- pH: using a digital pH meter (Model -671P. JENCO.U.S.A).

- Lycopene (mg/100gm juice): It was determined as the method described by Ranganna (1979).

- TSS (\%): It was determined by using Carl Zeis refractometer.

Statistical analysis of the obtained data was carried out according to statistical analysis of variance
(Snedecor and Cochran, 1980). Duncan's multiple range tests was used for comparison among means (Duncan, 1958).

\section{RESULTS AND DISCUSSION}

\section{Marketable Yield \\ Effect of calcium sources:}

Number of fruits/ plant and average fruit weight were significantly increased with foliar application of calcium chloride $\left(\mathrm{CaCl}_{2}\right)$ and calcium chelate $(\mathrm{Ca}-$ chelate) (Table 2). Total yield/ fed. was significantly increased with application of $\mathrm{CaCl}_{2}$ and calcium carbonate $\left(\mathrm{CaCO}_{3}\right)$ in the $1^{\text {st }}$ season and with all $\mathrm{Ca}$ sources in the $2^{\text {nd }}$ one compared to control treatment. The increment in yield and its components due to foliar application of calcium might be attributed to the vital role of calcium as one of the essential macroelements necessary for plant growth. It is used for maintenance of the plant cell structure, resistance to environmental stresses, viz. salinity, drought, chilling, heat, etc. (Mestre et al., 2012). Calcium also inhibit the flower abscission and delays leaf senescence in additaion enzyme activation ( Mengel and Kirkby, 1978), and stimulate the accumulation of phytoalexin, which implicated in the defense mechanisms of plants against fungal attacks (Zook et al., 1987; Aghofack- Nguemezi et al., 2014) and consequantly lead to increase in chloroohyll content, laef area/ plant, photo-assimilation and plant growth. The increment in plant growth increased number of flowers/cluster, number of fruits/cluster, number of fruits/plant, fruits weight and this in turn reflected on yield/ha. (Aghofack-Nguemezi and Tachago, 2010; Mestre et al., 2012; Elbeik, 2014; Ilyas et al., 2014). On the other hand, Rab and Haq (2012) found that there were no significant differences between control and foliar application of $\mathrm{CaCl}_{2}$ on tomato fruit weight and yield/fed.

Effect of time of application:

Data in Table 2 reveal that number of fruits/ plant was increased with foliar application of calcium at 15 days from flowering, but fruit weight was increased with $\mathrm{T}_{1}$ and $\mathrm{T}_{3}$ in the $1^{\text {st }}$ season. The previous parameters were not significantly affected in the second season. In the same trend, yield/ fed. were not significantly affected by time of Ca application in both season. Non significant differences were found among Ca time of application treatments is probably due to supplying tomato plant with calcium at the critial plant growth period and fruit setting is very important to overcome the high needs of tomato plants to calcium. The obtained results are coincide with those reported by Lewandowski (2003) who found that spraying strawberry plants with $\mathrm{CaCl}_{2}$ at petal fall stage or at 5 days intervals from the previous treatment did not affect total marketable fruit yield, berry fruit weight and number of deformed fruits. Application of calcium chlorid at high rates or at close frequent intervals decreased total marketable yield. Elbeik (2014) found negative effect on tomato plant growth as well as the yield due to foliar application of $\mathrm{Ca}$ chloride every 5 days compared to control treatment or application every 


\section{El-Tantawy, E. M. and M.I. Mahmoud}

15 days, and these ruslts refer to $\mathrm{Cl}$ toxicity and its negative effect on plant growth (Srivastava and Gupta, 1996). On the other hand, increasing $\mathrm{Ca}^{2+}$ concentration increased total fruit yield. The positive impact of extra $\mathrm{Ca}^{2+}$ on fruit yield could be related with the increase of $\mathrm{Ca}^{2+}$ levels in leaves favouring the fruit production at expenses of vegetative growth (Rubio et al.,2009).

Effect of interaction: Concerning number of fruits/plant, data in Table 3 show significant differences among the interaction treatments on number of fruits/plant. Application of $\mathrm{Ca}$ as calcium chloride after 15 days from flowering recorded the highest value in the $1^{\text {st }}$ season, while the same previous treatment as well as the interaction between application of $\mathrm{Ca}$ as calcium carbonate (at flowering) were the superior treatments in the sceond season with no significant differences when compared with application of calcium chloride (at flowering) or calcium carbonate (after 15 days from flowering). The same data reveal that fruit weight was significantly increased with application of calcium chelate (after 15 days from flowering) without significant difference with application of calcium chelate twice (at flowering + after 15 days from flowering) or once at flowering as well as with application of calcium chloride at flowering in the second season. Yield/fed. were significantly increased with application of $\mathrm{Ca}$ as calcium chloride or calcium carbonate (at flowering or at 15 days after flowering) in the $1^{\text {st }}$ season, while all interactiuon treatments between calcium sources and appliction times increased yield/fed. copmpared to control treatments in the $2^{\text {nd }}$ season. The increments in yield due to application of calcium compared to control may be owe to the vital role of $\mathrm{Ca}$ in plant growth and fruit setting and the chosen suitable time for $\mathrm{Ca}$ folir application. Calcium ion may also stimulate the accumulation of phytoalexin, a compound known to be implicated in the defense mechanisms of plants as a result of fungal attacks and resistance to bacterial and viral disease (Zook et al., 1987; Usten et al, 2006). Calcium also increased photosynthetic rate, flowers/cluster, fruit/ cluster, fruit/plant and fresh fruit yield was observed by Rab and Haq (2012), Yang et al. (2012) and AghofackNguemezi et al. (2014). The increment in yield may be attributed to increase in number of fruits/ plant due to application of $\mathrm{Ca}$ which play a role in the inhibition of abscission (Mengle and Kerkby, 1978) and decrease the abscision flowers and fruits (Smit and Combrink, 2005; Ilyas et al., 2014). Additionally, application of $\mathrm{Ca}$ at the critical periods of plant growth, rapid growth and fruit setting is important to increase marketability of fruits (Lester and Grusak, 2004), at which fruits deformed occurs mostly during a period of high cellular $\mathrm{Ca}$ demand, when fruit growth is accelerated or Ca dilivery to the fruits is limited (Bradfield and Guttridge, 1984; Ho, 1989; Marcelis and Ho, 1999).

2- Unmarketable yield: unmarketable yield was estimated as fruits infected by blossom- end rot (BER).

Effect of calcium sources:

Data in Table 2 reveal that there were significant differences detected among $\mathrm{Ca}$ sources on unmarketable yield components. Control treatment recorded the highest values of infected yield with BER incidence per fed. compared to all tested sources of calcium. Application of calcium as calcium carbonate or calcium chelate recorded the lowest values of unmarketable yield fed. The increment in BER incidence on yield observed with control treatment may be owe to the low Ca content in fruit tissue (Elbeik, 2014) which resulted from $\mathrm{Ca}$ deficiency in its tissues (Mengel and Kirkby, 2001). In this connection Del-Amor and Marcelis (2003) showed that the BER in tomato fruit is a physiological disorder resulting from calcium deficiency and it may occur in all the most producing areas of the world (Casado-Vela et al., 2005). The decrease of BER yield due to application of $\mathrm{Ca}$ compared to control treatment may be due to the critical role of $\mathrm{Ca}$ in maintaining plant cells structure and its resistance to environmental stress (Mester et al., 2012) and stability of biomembranes, and $\mathrm{Ca}$ polyglacturonates required in the middle lamella for cell wall stability (Marschner, 1986). These results are coincide with those reported by Schmitz-Eiberger et al. (2002), Rubio et al. (2009), Byeon et al. (2012), Mester et al. (2012), Rab and Haq (2012) and Ilyas et al. (2014) who concluded that application of $\mathrm{Ca}$ in high concentrations regardless the source can reduced the fruits infected by BER.

Effect of time of application:

Data in Tale 2 reveal that there were no significant differences among the $\mathrm{Ca}$ times of application treatments on BER incidence in tomato yield/ fed. These results may be attributed to application of calcium was practiced at the rapid vegetative growth and fruit setting in the same time at the period of high cellular Ca demand. Byeon et al. (2012) showed that during the first fruit setting period, more than $60 \%$ of pepper fruits showed the symptoms of blossom-end rot and calcium application during the rapid vegetative growth and fruit setting period could be suggested as a preventive step to overcome the local $\mathrm{Ca}$ deficiency inducing BER of pepper fruits. The insignificant differences among the treatments due to spraying $\mathrm{Ca}$ at flowering or setting period may be also due to the high content of calcium in fruits and consequantly $\mathrm{Ca}$ did not reflect an effect on deformed fruits as mentioned by Lewandowski (2003) on strawberry.

\section{Effect of interaction:}

Data in Table 3 reveal that BER of tomato fruits was increased in all control interaction treatments specially in the second season expressed as infected yield / fed. In addition, sparying tomato plants with $\mathrm{Ca}$ as calcium chelate combined with $\mathrm{T}_{1}, \mathrm{~T}_{2}$ and $\mathrm{T}_{3}$ recorded the lowest values of infected yield with BER followed by the interaction between calcium carbonate and its times of application and spraying of $\mathrm{Ca}$ as calcium chloride at the three times of application, respectively. It is clear that there were no significant differences among the time of application with the three sources of calcium which the effect of application time is weak. So, addition of $\mathrm{Ca}$ to tomato plants specially at flowering or fruit setting is very important to decrease 
tomato fruit incidence with BER. In this connection, Goodwin (1978) showed that the concentration of GA in tomato pericarp is high at fruit development. At this time, fruit growth by cell expansion is rapid, especially at fruit blossom-end. This phase is of greatest risk of BER incidence. Whereas GA concentration is high, the concentration of $\mathrm{Ca}^{2+}$ is strictly reduced in this period, and this rapid growth rates may increase the risk that the tissue content of $\mathrm{Ca}^{2+}$ falls below the critical level required for cell wall stabilization and membrane integrity (Marschner, 1993). Saur (2014) explained that under condition of apoplastic $\mathrm{Ca}$, the plasma membrane may become leaky, leading to cell plasmolysis, cell death and thus BER incidence. In this case, spraying plants with $\mathrm{Ca}^{2+}$ salts during fruit set and development may help to reduce the incidence of BER. Byeon et al.

( 2012) came to silmilar results with spraying pepper plants with $\mathrm{Ca}$ which decreased the incidence of BER from $62.6 \%$ to $19.2 \%$.

Table 2: Effect of calcium sources and its time of application on marketable and unmarketable yield of tomato during 2011/2012 and 2012/2013 seasons.

\begin{tabular}{|c|c|c|c|c|c|c|c|c|}
\hline $\begin{array}{l}\text { Parameters } \\
\text { Treatments } \\
\end{array}$ & $\begin{array}{l}\text { Number of } \\
\text { fruits/plant }\end{array}$ & $\begin{array}{l}\text { Avg. fruit } \\
\text { weight } \\
\text { (gm) }\end{array}$ & $\begin{array}{l}\text { Marketable } \\
\text { yield/fed. } \\
\text { (ton) }\end{array}$ & $\begin{array}{l}\text { Unmarketable } \\
\text { yield/fed. } \\
\text { (ton) }\end{array}$ & $\begin{array}{l}\text { Number of } \\
\text { fruits/plant }\end{array}$ & $\begin{array}{l}\text { Avg. fruit } \\
\text { weight } \\
\text { (gm) }\end{array}$ & $\begin{array}{c}\text { Marketable } \\
\text { yield/fed. } \\
\text { (ton) }\end{array}$ & $\begin{array}{c}\text { Unmarketable } \\
\text { yield/fed. } \\
\text { (ton) }\end{array}$ \\
\hline Calcium sources & \multicolumn{4}{|c|}{ First season } & \multicolumn{4}{|c|}{ Second season } \\
\hline Without calcium & $33.2 \mathrm{c}$ & $63.4 \mathrm{c}$ & $19.1 b$ & $1.20 \mathrm{a}$ & $34.1 \mathrm{c}$ & $61.0 \mathrm{c}$ & $19.3 b$ & $1.06 \mathrm{a}$ \\
\hline Calcium chloride & $50.8 \mathrm{a}$ & $59.8 \mathrm{c}$ & $27.2 \mathrm{a}$ & $0.75 b$ & $48.5 \mathrm{a}$ & $62.9 \mathrm{bc}$ & $28.0 \mathrm{a}$ & $0.76 b$ \\
\hline Calcium carbonate & $43.2 b$ & $68.1 b$ & $26.9 \mathrm{a}$ & $0.38 \mathrm{c}$ & $44.4 b$ & $68.8 \mathrm{~b}$ & $28.3 \mathrm{a}$ & $0.45 \mathrm{c}$ \\
\hline Calcium chelate & $26.2 \mathrm{~d}$ & $82.0 \mathrm{a}$ & $20.1 b$ & $0.33 c$ & $36.0 \mathrm{bc}$ & $80.7 \mathrm{a}$ & $27.2 \mathrm{a}$ & $0.33 c$ \\
\hline Time of application & \multicolumn{4}{|c|}{ First season } & \multicolumn{4}{|c|}{ Second season } \\
\hline T1 (at flowering) & $33.5 b$ & $73.3 \mathrm{a}$ & $22.8 \mathrm{a}$ & $0.63 \mathrm{a}$ & $37.3 \mathrm{a}$ & $71.0 \mathrm{a}$ & $24.9 \mathrm{a}$ & $0.68 \mathrm{a}$ \\
\hline T2 (after 15 days) & $45.2 \mathrm{a}$ & $63.4 b$ & $23.0 \mathrm{a}$ & $0.72 \mathrm{a}$ & $44.7 \mathrm{a}$ & $65.9 \mathrm{a}$ & $26.9 \mathrm{a}$ & $0.61 \mathrm{a}$ \\
\hline $\begin{array}{l}\text { T3 (at flowering + } \\
15 \text { days) }\end{array}$ & $36.2 b$ & $68.3 \mathrm{ab}$ & $22.5 \mathrm{a}$ & $0.68 \mathrm{a}$ & $40.3 \mathrm{a}$ & $68.2 \mathrm{a}$ & $25.3 \mathrm{a}$ & $0.67 \mathrm{a}$ \\
\hline
\end{tabular}

*Values having the same alphabetical letter (s) did not significantly differ at 0.05 level of significance according to Duncan's multiple range test.

Table 3: Effect of interaction between calcium sources and its time of application on marketable and unmarketable yield of tomato during 2011/2012 and 2012/2013 seasons.

\begin{tabular}{|c|c|c|c|c|c|c|c|c|c|}
\hline Treatments & Parameters & $\begin{array}{l}\text { Number of } \\
\text { fruits/plant }\end{array}$ & $\begin{array}{l}\text { Avg. } \\
\text { fruit } \\
\text { weight } \\
\text { (gm) }\end{array}$ & $\begin{array}{l}\text { Marketable } \\
\text { yield/fed. } \\
\text { (ton) }\end{array}$ & $\begin{array}{l}\text { Unmarketabl } \\
\text { e yield/fed. } \\
\text { (ton) }\end{array}$ & $\begin{array}{c}\text { Number } \\
\text { of } \\
\text { fruits/plan } \\
t\end{array}$ & $\begin{array}{l}\text { Avg. fruit } \\
\text { weight } \\
\text { (gm) }\end{array}$ & $\begin{array}{l}\text { Marketa } \\
\text { ble } \\
\text { yield/fed. } \\
\text { (ton) }\end{array}$ & $\begin{array}{c}\text { Unmarketa } \\
\text { ble } \\
\text { yield/fed. } \\
\text { (ton) } \\
\end{array}$ \\
\hline \multirow[t]{3}{*}{ Calcium sources } & $\begin{array}{c}\text { Time of } \\
\text { application }\end{array}$ & \multicolumn{4}{|c|}{ First season } & \multicolumn{4}{|c|}{ Second season } \\
\hline & At flowering & $34.7 \mathrm{~g}$ & $60.4 \mathrm{efg}$ & $19.3 \mathrm{c}$ & $1.07 \mathrm{~b}$ & $35.3 c$ & $58.7 \mathrm{ef}$ & $19.3 \mathrm{c}$ & $1.05 \mathrm{a}$ \\
\hline & $\begin{array}{c}\text { After } 15 \text { days } \\
\text { At }\end{array}$ & $33.3 \mathrm{~h}$ & $63.5 \mathrm{def}$ & $18.5 \mathrm{c}$ & $1.48 \mathrm{a}$ & $32.3 c$ & $61.3 \mathrm{ef}$ & $18.5 \mathrm{c}$ & $1.09 \mathrm{a}$ \\
\hline \multirow{3}{*}{ Without calcium } & $\begin{array}{c}\text { flowering }+15 \\
\text { days }\end{array}$ & $31.5 \mathrm{i}$ & $66.3 \mathrm{de}$ & $19.5 \mathrm{c}$ & $1.17 \mathrm{~b}$ & $34.4 \mathrm{c}$ & $62.9 \mathrm{def}$ & $20.2 \mathrm{bc}$ & $1.05 \mathrm{a}$ \\
\hline & At flowering & $38.2 \mathrm{f}$ & $75.2 \mathrm{bc}$ & $26.8 \mathrm{ab}$ & $0.75 \mathrm{c}$ & $39.8 b c$ & $73.3 \mathrm{bcd}$ & $27.3 \mathrm{ab}$ & $0.84 b$ \\
\hline & $\begin{array}{c}\text { After } 15 \text { days } \\
\text { At }\end{array}$ & $65.7 \mathrm{a}$ & $47.7 \mathrm{~h}$ & $29.2 \mathrm{a}$ & $0.76 \mathrm{c}$ & $55.2 \mathrm{a}$ & $55.3 \mathrm{f}$ & $28.6 a$ & $0.69 b$ \\
\hline \multirow{3}{*}{ Calcium chloride } & $\begin{array}{c}\text { flowering }+15 \\
\text { days }\end{array}$ & $48.4 \mathrm{c}$ & $56.6 \mathrm{fg}$ & $25.6 b$ & $0.74 \mathrm{c}$ & $50.3 \mathrm{ab}$ & $59.9 \mathrm{ef}$ & $28.1 \mathrm{a}$ & $0.76 b$ \\
\hline & At flowering & $38.8 \mathrm{e}$ & $80.9 b$ & $29.2 \mathrm{a}$ & $0.39 \mathrm{~d}$ & $39.8 b c$ & $77.2 \mathrm{abc}$ & $28.8 \mathrm{a}$ & $0.49 \mathrm{~cd}$ \\
\hline & After 15 days & $51.8 \mathrm{~b}$ & $54.1 \mathrm{gh}$ & $26.1 \mathrm{ab}$ & $0.27 \mathrm{~d}$ & $52.5 \mathrm{a}$ & $62.0 \mathrm{ef}$ & $30.3 \mathrm{a}$ & $0.33 \mathrm{~d}$ \\
\hline \multirow[t]{4}{*}{ Calcium carbonate } & At & & & & & & & & \\
\hline & $\begin{array}{c}\text { flowering }+15 \\
\text { days }\end{array}$ & $39.2 d$ & $69.4 \mathrm{~cd}$ & $25.4 b$ & $0.50 \mathrm{~cd}$ & $40.8 \mathrm{bc}$ & $67.0 \mathrm{cde}$ & $25.7 \mathrm{abc}$ & $0.53 \mathrm{c}$ \\
\hline & At flowering & 22.41 & $76.8 \mathrm{~b}$ & $16.1 \mathrm{c}$ & $0.32 \mathrm{~d}$ & $34.0 \mathrm{c}$ & 75.0abc & 24.1abc & $0.33 \mathrm{~d}$ \\
\hline & After 15 days & $30.2 \mathrm{j}$ & $88.4 \mathrm{a}$ & $24.9 \mathrm{~b}$ & $0.36 \mathrm{~d}$ & $38.4 \mathrm{c}$ & $85.1 \mathrm{a}$ & $30.3 \mathrm{a}$ & $0.32 d$ \\
\hline \multirow[t]{2}{*}{ Calcium chelate } & At & & & & & & & & \\
\hline & $\begin{array}{c}\text { flowering }+15 \\
\text { days }\end{array}$ & $25.8 \mathrm{k}$ & $80.8 b$ & $19.5 \mathrm{c}$ & $0.30 \mathrm{~d}$ & $35.6 \mathrm{c}$ & $82.2 \mathrm{ab}$ & $27.2 \mathrm{ab}$ & $0.32 \mathrm{~d}$ \\
\hline
\end{tabular}




\section{3- Marketability (\%) and unmarketability (BER incidence \%) \\ Effect of calcium sources:}

The data in Table 4 reveal that all sources of $\mathrm{Ca}$ applied increased the marketability $\%$ of tomato fruits and decreased BER\% in the $1^{\text {st }}$ season, while spraying with $\mathrm{Ca}$ as $\mathrm{Ca}$ - carbonate or $\mathrm{Ca}$-chelate recorded the highest and lowest values of both marketability $\%$ and BER incidence \%, respectively in the second one. Control tratments recorded the lowest and highest values of marketability \% and BER incidence \% in both seasons, respectively. Foliar application of $\mathrm{Ca}$ increased the fruit marketability \% from $98.58,98.38$ and $97.29 \%$ for Ca-carbonate, $\mathrm{Ca}$-chelate and $\mathrm{Ca}$ chloride in the $1^{\text {st }}$ season, respectively compared to $(93.9 \%)$ control treatment and from $98.65,98.40$ and $97.25 \%$ for $\mathrm{Ca}$ chelate, Ca-carbonate and Ca-chloride in the $2^{\text {nd }}$ season, respectively compared to $(94.74 \%)$ control treatment. Application of $\mathrm{Ca}$ decrease of $\mathrm{BER} \%$ incidence from 6.\% control treatment to $1.42,1.62$ and $2.71 \%$ for $\mathrm{Ca}$ carbonate, Ca-chelate and $\mathrm{Ca}$ - chloride in the $1^{\text {st }}$ season, respectively and from $5.26 \%$ control treatment to 1.35 , 1.60 , and $2.75 \%$ for $\mathrm{Ca}$-chelate, $\mathrm{Ca}$-carbonate and $\mathrm{Ca}$ chloride in the $2^{\text {nd }}$ season, respectively. The increment of fruit marketability $\%$ and decrease in BER\% incidence due to application of $\mathrm{Ca}$ may be owe much to the increase of marketable yield and decrease in infected yield with BER per fed. (Table 2) compared to control treatmets. These results under calcareous soil and salinity water irrigation which increase soil $\mathrm{pH}$ and consequantly reduce the availability or loss or fixation of almost all nutrients (Imas, 2000) and foliar application of $\mathrm{Ca}$ to plant is required for middle lamella and cell wall stability (Marschner, 1986; Saur, 2014) and for building new cell walls and membranes, and as a cytosolic signal in the form of a counter-cation in the enlarging vacuole (Ho and White, 2005). In addition, it affected the activity of the ascorbate-glutathione enzymes which lead to more calcium in tomato fruits (Waterland et al., 2010; Setha, 2012) .This could cause the break-down of cellular homeostasis, the inhibition of other enzymes responsible for $\mathrm{H}_{2} \mathrm{O}_{2}$ detoxification, and ultimately an increase of lipid peroxidation in tomato plants therefore, BER incidence (Schmitz-Eiberger et al., 2002; Mestre et al., 2012), Ca application also supressed the induction and the effect of GA and consequantly inhibited the development of BER (Saur, 2014). Additionally, Ca defficiency create losses up to $50 \%$ of tomato yield in all tomato producing areas of the world (Casado-Vela et al., 2005) and application of $\mathrm{Ca}$ increased calcium concentration in fruit tissues and supressed the incidence of BER, which decreased from $62.6 \%$ to $19.2 \%$ (Byeon et al., 2012). Rab and Haq (2012) found that application of $\mathrm{Ca}$ at concentration of $0.6 \%$ decreased BER \% incidence in tomato fruits from $17.56 \%$ in control to $10.12 \%$. The same result was found by Ilyas et al., (2014) who found that application of $\mathrm{Ca}$ decreased BER\% in tomato fruits from $15.97 \%$ as control treatment to $8.22 \%$ with $\mathrm{Ca}$ application. $\mathrm{Ca}$ foliar application increased tomato fruit marketability and decreased BER\% incidence (Hao and Papadopoulos, 2004; Rubio et al., 2009).

\section{Effect of application time:}

The data in Table 4 illustrate that there were no significant differences among all application times on fruit marketability\% and BER\% incidence in both seasons. These results may be attributed to the effect of application times on marketable yield per fed. and unmarketable yield (infected fruits) (Table 2) wherin the same trend of resules were found. As well as it may be owed to apply of calcium at the rapid vegetative growth of tomato plants and fruit setting periods wherein $\mathrm{Ca}$ concentration in fruits decreased after flower anthesis, and fruit growth is accelerated and fruits needs high cellular Ca demand (Bradfield and Guttridge, 1984; Ho, 1989; Marcelis and Ho, 1999). Lester and Grusak (2004) found that the marketability of honey dew fruits were increased when plants sprayed four tims by $\mathrm{Ca}$ application. Calcium application during the rapid vegetative growth and fruit setting periods may increase the concentartion of $\mathrm{Ca}$ in setting fruits as a preventive step to overcome the local $\mathrm{Ca}$ deficiency inducing blossom-end rot of pepper fruits (Lester and Grusak, 2004; Byeon et al., 2012).

\section{Effect of interaction:}

The data in Table 5 reveal that the interaction between $\mathrm{Ca}$ foliar application as calcium carbonate with treatments of $\mathrm{T}_{1}$ or $\mathrm{T}_{3}$ as well as application of $\mathrm{Ca}$ as calcium chelate with $\mathrm{T}_{1}, \mathrm{~T}_{2}$ and $\mathrm{T}_{3}$ were the superior interaction treatments in $1^{\text {st }}$ season and $2^{\text {nd }}$ seasons wherein, it recorded the highest values of fruit marketability $\%$ and the lowest values of BER\% incidence. On the other hand, control treatments recorded the lowest values of fruit marketability \% and highest BER\% incidence values in both seasons. It could be concoluded that regardless the time of $\mathrm{Ca}$ application, application of calcium as carbonate or chelate sources increased the fruit marketability $\%$ and decreased BER\% incidence compared to $\mathrm{Ca}$ as chloride or without application of $\mathrm{Ca}$ in both seasons. The obtained results may be owed to the effect of $\mathrm{Ca}$ application on marketable yield and unmarketable yield which show decrease in infected fruit yield (Tables 4, 5 ), as well as to the supply of calcium at the critical stage of plant growth and fruit setting which need more calcium. In this connection, Elbeik (2014) found that spraying tomato plants with ca as Ca-chelate every 15 days recorded the highest value of marketable yield, while sprying with $\mathrm{Ca}$ as calcium chloride every 5 days recorded the lowest value in this respect. In addition, application of $\mathrm{Ca}$ as $\mathrm{Ca}$-chelate every 5 or 15 days recorded the lowest values of BER\%, while sprying $\mathrm{Ca}$ as calcium chloride every 15 days recorded the highest BER\%. On the other hand, Lewandowski (2003) found that number of strawberry deformed fruits did not significantly affected by spraying with $\mathrm{CaCl}_{2}$ at petal fall stage or 5 days intervals from petal fall stage. 
Table 4: Effect of calcium sources and its time of application on marketability and BER \% of tomato during 2011/2012 and 2012/2013 seasons.

\begin{tabular}{|c|c|c|c|c|}
\hline Parameters & $\begin{array}{c}\text { Marketability } \\
(\%)\end{array}$ & $\begin{array}{c}\text { Unmarketability } \\
(\text { BER ) } \\
(\%)\end{array}$ & Marketability (\%) & $\begin{array}{c}\text { Unmarketability } \\
\text { (BER ) } \\
(\%)\end{array}$ \\
\hline Calcium sources & \multicolumn{2}{|c|}{ First season } & \multicolumn{2}{|c|}{ Second season } \\
\hline Without calcium & $93.90 \mathrm{~b}$ & $6.10 \mathrm{a}$ & $94.74 \mathrm{c}$ & $5.26 \mathrm{a}$ \\
\hline Calcium chloride & $97.29 \mathrm{a}$ & $2.71 \mathrm{~b}$ & $97.25 \mathrm{~b}$ & $2.75 b$ \\
\hline Calcium carbonate & $98.58 \mathrm{a}$ & $1.42 \mathrm{~b}$ & $98.40 \mathrm{a}$ & $1.60 \mathrm{c}$ \\
\hline Calcium chelate & $98.38 \mathrm{a}$ & $1.62 b$ & $98.65 \mathrm{a}$ & $1.35 \mathrm{c}$ \\
\hline Time of application & \multicolumn{2}{|c|}{ First season } & \multicolumn{2}{|c|}{ Second season } \\
\hline $\mathrm{T} 1$ (at flowering) & $97.19 \mathrm{a}$ & $2.81 \mathrm{a}$ & $97.12 \mathrm{a}$ & $2.88 \mathrm{a}$ \\
\hline T2 (after 15 days) & $96.90 \mathrm{a}$ & $3.10 \mathrm{a}$ & $97.41 \mathrm{a}$ & $2.59 \mathrm{a}$ \\
\hline $\mathrm{T} 3$ (at flowering+15 days) & $97.01 \mathrm{a}$ & $2.99 \mathrm{a}$ & $97.26 \mathrm{a}$ & $2.74 \mathrm{a}$ \\
\hline
\end{tabular}

Table 5: Effect of interaction between calcium sources and its time of application on marketability and BER (\%) of tomato during 2011/2012 and 2012/2013 seasons.

\begin{tabular}{|c|c|c|c|c|c|}
\hline Treatments & Parameters & $\begin{array}{c}\text { Marketability } \\
(\%)\end{array}$ & $\begin{array}{c}\text { Unmarketability } \\
\text { (BER ) } \\
(\%))\end{array}$ & $\begin{array}{c}\text { Marketability } \\
(\%)\end{array}$ & $\begin{array}{c}\text { Unmarketability } \\
\text { (BER) } \\
(\%)\end{array}$ \\
\hline \multirow[t]{2}{*}{ Calcium sources } & Time of application & \multicolumn{2}{|c|}{ First season } & \multicolumn{2}{|c|}{ Second season } \\
\hline & At flowering & $94.75 \mathrm{c}$ & $5.25 b$ & $94.81 d$ & $5.19 \mathrm{a}$ \\
\hline \multirow[t]{3}{*}{ Without calcium } & After 15 days & $92.61 d$ & $7.39 \mathrm{a}$ & $94.44 d$ & $5.56 \mathrm{a}$ \\
\hline & At flowering +15 days & $94.33 c$ & $5.67 \mathrm{~b}$ & $94.98 \mathrm{~d}$ & $5.02 \mathrm{a}$ \\
\hline & At flowering & $97.26 \mathrm{~b}$ & $2.74 \mathrm{c}$ & $96.97 \mathrm{c}$ & $3.03 \mathrm{~b}$ \\
\hline \multirow[t]{2}{*}{ Calcium chloride } & After 15 days & $97.42 b$ & $2.58 \mathrm{c}$ & $97.41 b c$ & $2.59 b c$ \\
\hline & At flowering +15 days & $97.19 b$ & $2.81 \mathrm{c}$ & $97.37 \mathrm{bc}$ & $2.63 \mathrm{bc}$ \\
\hline \multirow{4}{*}{$\begin{array}{l}\text { Calcium } \\
\text { carbonate }\end{array}$} & At flowering & $98.70 \mathrm{a}$ & $1.30 \mathrm{~d}$ & $98.32 \mathrm{ab}$ & $1.68 \mathrm{~cd}$ \\
\hline & After 15 days & $98.99 \mathrm{a}$ & $1.01 \mathrm{~d}$ & $98.91 \mathrm{a}$ & $1.09 \mathrm{~d}$ \\
\hline & At flowering +15 days & $98.05 \mathrm{ab}$ & $1.95 \mathrm{~cd}$ & $97.97 \mathrm{abc}$ & $2.03 \mathrm{bcd}$ \\
\hline & At flowering & $98.06 \mathrm{ab}$ & $1.94 \mathrm{~cd}$ & $98.37 \mathrm{ab}$ & $1.63 \mathrm{~cd}$ \\
\hline \multirow[t]{2}{*}{ Calcium chelate } & After 15 days & $98.58 \mathrm{a}$ & $1.42 \mathrm{~d}$ & $98.87 \mathrm{a}$ & $1.13 \mathrm{~d}$ \\
\hline & At flowering +15 days & $98.48 \mathrm{a}$ & $1.52 \mathrm{~d}$ & $98.71 \mathrm{a}$ & $1.29 \mathrm{~d}$ \\
\hline
\end{tabular}

*Values having the same alphabetical letter (s) did not significantly differ at 0.05 level of significance according to Dunca n's multiple range test.

\section{Physical Parameters}

\section{Effect of calcium sources:}

Concerning fruit weight loss, the data presented

in Table 6 show that control treatmrnt significantly increased fruit weight loss in both seasons, and application of calcium as calcuim carbonate recordrd the lowest values of fruit weight loss in the $1^{\text {st }}$ season compared to calcium chloride and calcium chelate, with no significant differences among calcium chloride, calcuim carbonate and calcium chelate in the second season. As regard to fruit firmness, the same data show that there were no significnt differences among all sources of $\mathrm{Ca}$ at the initial time of storage in the $1^{\text {st }}$ season, but firmness at the end of storage period increased with application of $\mathrm{Ca}$ as calcium chloride without significant differences when compared with calcuim carbonate and calcium chelate. In addition, spraying with $\mathrm{Ca}$ as $\mathrm{Ca}$ carbonate recorded the highest value of firmness at the initial time of storage compared to control treatment, and spraying with both calcium chloride and aclcium chelate, but at the end of storage period, control treatment recorded the lowest value of firmness compared to the other Ca applied sources. The increments in weight loss and decrease in firmness in control treatment compared to application of calcium may be owe to the vital role of $\mathrm{Ca}$ in building plant cell wall middel lamella and stability of bio-membranes, and Ca-polyglacturonates required in the middle lamella for cell wall stability and thus limit cell expantion (Marschner, 1986; Saur, 2014). The effect of Ca application on tomato fruits weight loss and firmness are in harmony with those reported by Bhattarai and Gautam (2006) who observed that weight loss of tomato fruits during storage period was lower than control treatment due to application of $\mathrm{CaCl}_{2}$. This may be owe to the role of $\mathrm{Ca}$ in plant as an important nutrient in structural of middle lamellae. Softening of fruits is mainly due to weaking of middle lamella during ripenning. Calcium helps to bind polygalactonic acid each other,formation of cation cross bridges between uronic acid groups (Sams et. al., 1993) which may induce lower weight loss and higher fruit firm and make the membrane strong and rigid. Calcium is essential for stability of biomembranes, and $\mathrm{Ca}$ - polyglacturonates are required in the middle lamella for cell wall stability (Marschner, 1986). Spraying calcium clorid can delay tomato fruit maturity and senescence and it may increase fruit firmness and organic acid content, decrease and delay peak value of respiration, restrain the increasing of membrane osmosis (Schmitz-Eiberger et al., 2002; Chen et al., 2006). The increment of hardness due to application of $\mathrm{Ca}$ my be also attributed to the significant increment of calcium content in both inner and outer pericarp regions of fruits. Calcium chloride treated tomatoes produced ethylene at significantly lower levels and delayed climacteric peak 
to a certain extent and this consequantly showed significantly higher firmness (Senevirathna and Daundasekera, 2010). The increment in hardness as regard to increase in shelf life due to application of $\mathrm{Ca}$ compared to control treatment may be attributed to calcium is bound to calmodulin, which is one of the most common intracellular receptors to modulate many physiological processes. Aghofack-Nguemezi and Tachago (2010) found that application of fertilizeres containing $\mathrm{Ca}$ gave fruits with longer duration of ripening period than those from control plants. The length of time between the red-ripe stage and the trickling of $100 \%$ of tomato fruits (shelf-life) was mostly significantly prolonged, and it may be owe to $\mathrm{Ca}$ retained fruits firmness, calcium ion can delay the ripening and senescence by stabilizing cell membrane and increasing the rigidification of monolayers. Also several calcium-pectate interactions make the cell wall firmer (Carpita and McCann, 2000). In addition, foliar application of $\mathrm{Ca}$ as $\mathrm{CaCl}_{2}$ or Ca-chelate increased tomato fruit firmness ( $\mathrm{Rab}$ and Haq, 2012; Elbeik, 2014).

\section{Effect of application time:}

Data presented in Table 6 reveal that spraying tomato plants with $\mathrm{Ca}$ once at flowering recorded the highest fruit weight loss compared to $\mathrm{T}_{3}$ treatment. This means that the rate of fruit weight loss in case of sprying two times $\left(\mathrm{T}_{3}\right)$ is higher than spraying one time, specially at flowering stage. This situation was reversed in the $2^{\text {nd }}$ season, which did not reflect significant differences among application times regarding fruit weight loss. It is obevious from the same data that $\mathrm{Ca}$ application times had no significant effect on tomato fruit firmness in both seasons. It could be concluded that the effect of application time on fruit weight loss is fluctuate, in its effect on firmness parameters. The fluctuation effect of time of application on fruit weight loss and its insignificant effect on firmness paramrters may be attrhibuted to that the supply of $\mathrm{Ca}$ in conformity plant growth stages wherein the requirements of $\mathrm{Ca}$ is cumulative after anthesis (Byeon et al., 2012) and fruit growth which a period of high cellular Ca demand (Bradfield and Guttridge, 1984; Ho, 1989; Marcelis and Ho, 1999). Increasing Ca concentration may stimulate the role of ABA in fruit growth development (Aghofack-Nguemezi et al., 2014) and this lead to more calcium content in tomato fruits (Waterland et al., 2010; Setha, 2012) and this in turn increase the fruit firmness and consequantly the shelf life of tomato fruits.

\section{Effect of interaction:}

The data in Table 7 reveal that interaction treatments of control increased weight loss in both seasons, while the interaction between Ca-carbonate $\mathrm{x}$ spraying twice $\left(\mathrm{T}_{3}\right)$ as well as the interaction between application of Ca-chelate $\mathrm{x} \mathrm{T}_{1}$ recorded the lowest fruit weight loss in the $1^{\text {st }}$ and $2^{\text {nd }}$ seasons, respectively. Concerning fruit frmness, the data illustrate that firmness at the initial time of storage in the $1^{\text {st }}$ season did not show significant effect by the interaction treatments, while it had significant effecte in the $2^{\text {nd }}$ season. The highest firmness values were observed with foliar application of $\mathrm{Ca}$ as $\mathrm{Ca}$-chloride twice and application of $\mathrm{Ca}$ as $\mathrm{Ca}$-carbonate one time at after 15 day or two times at flowering + after 15 days of flowering in the second season. Similar trend for firmness was observed at the end of storage peroid in the second season. Control interaction treatments recorded the lowest fruit firmness values in both seasons. In this connection Lester and Grusak (2004) found that spraying honey dew plants with $\mathrm{Ca}$ (with regardless of sources) four times increased fruit firmness due to its higher content of $\mathrm{Ca}$ compared to control plants.

Table 6: Effect of calcium sources and its time of application on some physical parameters of tomato fruits during 2011/2012 and 2012/2013 seasons.

\begin{tabular}{|c|c|c|c|c|c|c|c|c|}
\hline $\begin{array}{l}\text { Parameters }_{\mathbf{I}} \\
\text { nents }\end{array}$ & $\begin{array}{c}\text { Fruit weight } \\
\text { loss } \\
(\text { gm) }\end{array}$ & $\begin{array}{c}\text { Firmness } \\
\text { at the } \\
\text { initial } \\
\text { time }\end{array}$ & $\begin{array}{c}\text { Firmness } \\
\text { after } 10 \text { days } \\
\text { of storage }\end{array}$ & $\begin{array}{l}\text { Decreasing } \\
\text { rate in } \\
\text { hardness }\end{array}$ & $\begin{array}{c}\text { Fruit weight } \\
\text { loss } \\
\text { (gm) }\end{array}$ & $\begin{array}{c}\text { Firmness } \\
\text { at the } \\
\text { initial } \\
\text { time }\end{array}$ & $\begin{array}{c}\text { Firmness } \\
\text { after } 10 \\
\text { days } \\
\text { of storage }\end{array}$ & $\begin{array}{l}\text { Decreasing } \\
\text { rate in } \\
\text { hardness }\end{array}$ \\
\hline Calcium sources & \multicolumn{4}{|c|}{ First season } & \multicolumn{4}{|c|}{ Second season } \\
\hline Without calcium & $4.80 \mathrm{a}$ & $2.92 \mathrm{a}$ & $2.31 \mathrm{~b}$ & $0.67 \mathrm{a}$ & $3.43 \mathrm{a}$ & $1.52 \mathrm{c}$ & $1.29 \mathrm{~b}$ & $0.232 \mathrm{a}$ \\
\hline Calcium chlorid & $3.77 \mathrm{ab}$ & $3.42 \mathrm{a}$ & $3.03 \mathrm{a}$ & $0.38 b$ & $2.00 \mathrm{~b}$ & $2.61 \mathrm{~b}$ & $2.38 \mathrm{a}$ & $0.232 \mathrm{a}$ \\
\hline Calcium carbonate & $2.88 \mathrm{~b}$ & $3.19 \mathrm{a}$ & $2.76 \mathrm{ab}$ & $0.44 b$ & $2.60 \mathrm{~b}$ & $3.11 \mathrm{a}$ & $2.79 \mathrm{a}$ & $0.317 \mathrm{a}$ \\
\hline Calcium chelate & $3.35 b$ & $3.32 \mathrm{a}$ & $2.92 \mathrm{ab}$ & $0 . .35 b$ & $2.05 \mathrm{~b}$ & $2.48 \mathrm{~b}$ & $2.27 \mathrm{a}$ & $0.211 \mathrm{a}$ \\
\hline Time of application & \multicolumn{4}{|c|}{ First season } & \multicolumn{4}{|c|}{ Second season } \\
\hline T1 (at flowering) & $4.40 \mathrm{a}$ & $3.28 \mathrm{a}$ & $2.82 \mathrm{a}$ & $0.462 \mathrm{a}$ & $2.14 \mathrm{a}$ & $2.07 \mathrm{a}$ & $1.84 \mathrm{a}$ & $0.227 \mathrm{a}$ \\
\hline T2 (after 15 days) & $3.69 \mathrm{ab}$ & $3.08 \mathrm{a}$ & $2.59 \mathrm{a}$ & $0.492 \mathrm{a}$ & $3.12 \mathrm{a}$ & $2.51 \mathrm{a}$ & $2.22 \mathrm{a}$ & $0.293 \mathrm{a}$ \\
\hline $\begin{array}{l}\text { T3 (at flowering+15 } \\
\text { days) }\end{array}$ & $3.01 \mathrm{~b}$ & $3.28 \mathrm{a}$ & $2.86 \mathrm{a}$ & $0.433 \mathrm{a}$ & $2.31 \mathrm{a}$ & $2.71 \mathrm{a}$ & $2.49 \mathrm{a}$ & $0.224 \mathrm{a}$ \\
\hline
\end{tabular}


Table 7: Effect of interaction between calcium sources and its time of application on some physical parameters of tomato fruits during 2011/2012 and 2012/2013 seasons.

\begin{tabular}{|c|c|c|c|c|c|c|c|c|c|}
\hline \multicolumn{2}{|l|}{ Treatments } & $\begin{array}{c}\text { Fruit weight } \\
\text { loss (gm) }\end{array}$ & $\begin{array}{c}\text { Firmness } \\
\text { at the } \\
\text { initial } \\
\text { time }\end{array}$ & $\begin{array}{l}\text { Firmness } \\
\text { after } 10 \text { days } \\
\text { of storage }\end{array}$ & $\begin{array}{l}\text { Decreasing } \\
\text { rate in } \\
\text { hardness }\end{array}$ & $\begin{array}{c}\text { Fruit } \\
\text { weight loss } \\
\text { (gm) }\end{array}$ & $\begin{array}{c}\text { Firmness } \\
\text { at the } \\
\text { initial } \\
\text { time }\end{array}$ & $\begin{array}{l}\text { Firmness } \\
\text { after } 10 \text { days } \\
\text { of storage }\end{array}$ & $\begin{array}{c}\text { Decreasing } \\
\text { rate in } \\
\text { hardness }\end{array}$ \\
\hline $\begin{array}{l}\text { Calcium } \\
\text { sources }\end{array}$ & Time of application & \multicolumn{4}{|c|}{ First season } & \multicolumn{4}{|c|}{ Second season } \\
\hline \multirow{3}{*}{$\begin{array}{l}\text { Without } \\
\text { calcium }\end{array}$} & At flowering & $4.94 \mathrm{ab}$ & $3.02 \mathrm{a}$ & $2.39 \mathrm{~cd}$ & $0.623 \mathrm{a}$ & $3.30 \mathrm{ab}$ & $1.26 \mathrm{~d}$ & $1.06 \mathrm{f}$ & $0.200 \mathrm{a}$ \\
\hline & After 15 days & $5.29 \mathrm{a}$ & $2.80 \mathrm{a}$ & $2.17 \mathrm{~d}$ & $0.633 \mathrm{a}$ & $3.20 \mathrm{ab}$ & $1.77 \mathrm{bcd}$ & $1.49 \mathrm{def}$ & $0.287 \mathrm{a}$ \\
\hline & At flowering +15 days & $4.19 \mathrm{a}-\mathrm{d}$ & $2.93 a$ & $2.37 \mathrm{~cd}$ & $0.770 \mathrm{a}$ & $3.80 \mathrm{a}$ & $1.52 \mathrm{~cd}$ & $1.31 \mathrm{ef}$ & $0.210 \mathrm{a}$ \\
\hline \multirow{3}{*}{$\begin{array}{l}\text { Calcium } \\
\text { chloride }\end{array}$} & At flowering & $3.84 \mathrm{~b}-\mathrm{e}$ & $3.37 \mathrm{a}$ & $3.00 \mathrm{ab}$ & $0.367 \mathrm{a}$ & $1.70 \mathrm{~d}$ & $1.97 \mathrm{bcd}$ & $1.83 \mathrm{c}-\mathrm{f}$ & $0.133 \mathrm{a}$ \\
\hline & After 15 days & $3.87 \mathrm{~b}-\mathrm{e}$ & $3.25 \mathrm{a}$ & $2.83 \mathrm{abc}$ & $0.417 \mathrm{a}$ & $2.89 \mathrm{abc}$ & $2.47 \mathrm{abc}$ & $2.23 \mathrm{a}-\mathrm{d}$ & $0.237 \mathrm{a}$ \\
\hline & At flowering +15 days & $3.57 \mathrm{cde}$ & $3.63 \mathrm{a}$ & $3.27 \mathrm{a}$ & $0.367 \mathrm{a}$ & $1.40 \mathrm{~d}$ & $3.40 \mathrm{a}$ & $3.07 \mathrm{a}$ & $0.327 \mathrm{a}$ \\
\hline \multirow{3}{*}{$\begin{array}{l}\text { Calcium } \\
\text { carbonate }\end{array}$} & At flowering & $4.64 \mathrm{abc}$ & $3.35 \mathrm{a}$ & $2.90 \mathrm{ab}$ & $0.450 \mathrm{a}$ & $2.09 \mathrm{~cd}$ & $2.70 \mathrm{ab}$ & $2.36 \mathrm{abc}$ & $0.340 \mathrm{a}$ \\
\hline & After 15 days & $2.84 \mathrm{e}$ & $3.13 \mathrm{a}$ & $2.64 \mathrm{bcd}$ & $0.493 \mathrm{a}$ & $3.37 \mathrm{ab}$ & $3.47 \mathrm{a}$ & $3.08 \mathrm{a}$ & $0.383 \mathrm{a}$ \\
\hline & At flowering +15 days & $1.15 \mathrm{f}$ & $3.10 \mathrm{a}$ & $2.73 b c$ & $0.367 \mathrm{a}$ & $2.34 \mathrm{bcd}$ & $3.15 \mathrm{a}$ & $2.92 \mathrm{ab}$ & $0.227 \mathrm{a}$ \\
\hline \multirow{3}{*}{$\begin{array}{l}\text { Calcium } \\
\text { chelate }\end{array}$} & At flowering & $4.16 \mathrm{a}-\mathrm{d}$ & $3.37 \mathrm{a}$ & $2.97 \mathrm{ab}$ & $0.407 \mathrm{a}$ & $1.45 \mathrm{~d}$ & 2.33a-d & $2.10 \mathrm{~b}-\mathrm{e}$ & $0.233 \mathrm{a}$ \\
\hline & After 15 days & $2.74 \mathrm{e}$ & $3.15 \mathrm{a}$ & $2.73 \mathrm{bc}$ & $0.423 \mathrm{a}$ & $3.00 \mathrm{abc}$ & $2.34 \mathrm{a}-\mathrm{d}$ & $2.07 \mathrm{~b}-\mathrm{e}$ & $0.267 \mathrm{a}$ \\
\hline & At flowering +15 days & $3.14 \mathrm{de}$ & $3.45 \mathrm{a}$ & $3.07 \mathrm{ab}$ & $0.233 \mathrm{a}$ & $1.70 \mathrm{~d}$ & $2.77 \mathrm{ab}$ & $2.63 \mathrm{abc}$ & $0.133 \mathrm{a}$ \\
\hline
\end{tabular}

*Values having the same alphabetical letter (s) did not significantly differ at 0.05 level of significance according to Dunca n's multiple range test.

\section{Fruit Quality}

Effect of calcium sources:

Concerning the content of V.C. the data in Fig.1 show that there were no significant differences among all sources of applied $\mathrm{Ca}$ on V.C. content in tomato fruits in both seasons. The same trend was found with $\mathrm{pH}$ in both seasons as well as TSS in the $1^{\text {st }}$ season wherein did not significantly affected by spraying tomato plants with any Ca source (Table 8), but TSS in the $2^{\text {nd }}$ season was increased significantly with Ca foliar application compared to control treatment. Application of $\mathrm{Ca}$ as $\mathrm{Ca}$ - chelate was the superior treatment for increasing TSS values at the initial and storage time without significant differences when compared with the other applied sources (Ca-chloride, $\mathrm{Ca}$-carbonate) while control treatment recorded the lowest values at both the initial and the end of storage period. As regard to lycopene content, the same data reveal that foliar application of $\mathrm{Ca}$ as $\mathrm{Ca}$-chloride recorded the lowest values at initial time of storage and at the end of storage period in both seasons followed by $\mathrm{Ca}$-carbonate. The highest increment in lycopene content during the storage period was observed with control treatment $(5$, $3.36 \%$ ), while the other sources of $\mathrm{Ca}$ recorded less lycopene content specially with $\mathrm{Ca}$-carbonate (1.2, $2.46 \%)$ followed by Ca-chloride $(3.23,2.86 \%)$ and $\mathrm{Ca}-$ chelate $(3.8,2.9 \%)$ in the $1^{\text {st }}$ and $2^{\text {nd }}$ season, respectively. The decrease in lycopene content due to application of $\mathrm{Ca}$ during storage period compared to control treatment may be owed to the role of $\mathrm{Ca}$ in ripening processes. Fruit ripening is a result of many processes including chlorophyll breakdown and synthesis of new carotenoids (Brady, 1987; Giovannoni, 2001). Ca application also inhibit the activity of pectinmethylesterase and polygalaturo-nase which are enzymes implied in the degradation of the cell wall pectin (Magee et al., 2003). Thus these findings significantly prolong the green-life of mature fruits and consequently increase fruits shelf life. The decrease in lycopene during storage period of fruits due to application of Ca may be owed to spraying $\mathrm{Ca}$ can delay tomato fruit maturity, ripening, and prolongation of the shelf life of the red-ripe ones as well as fruit senescence (Sharma et al., 1996; Chen et al., 2006; AghofackNguemezi and Tatchago, 2010). On the other hand, control treatments had high lycopen content after 14 days of storage compared to apllication of $\mathrm{Ca}$ as $\mathrm{CaCl}_{2}$ or Ca-chelate (Elbeik, 2014). In addition, TSS content in fruits significantly increased with $\mathrm{CaCl}_{2}$ treatment. However, there was no consistent relationship between $\mathrm{CaCl}_{2}$ treatment and the TSS content of tomato fruits at the end of the storage period. Similarly, there was no consistent relationship between $\mathrm{CaCl}_{2}$ treatment and titratable acidity (TA \%) of tomato fruits. However, spraying $6 \% \mathrm{CaCl}_{2}$ reflected a significant reduction in TA $\%$ in fruits. Although it was expected that $\mathrm{pH}$ would increase with higher $\mathrm{CaCl}_{2}$ levels according to TA \% values, $\mathrm{pH}$ was reduced to insignificant levels with the increase in $\mathrm{CaCl}_{2}$ concentration (Senevirathna and Daundasekera, 2010). Pila et al., (2010) found that control show decrease in TA\% and increase in TSS, lycopene and $\mathrm{pH}$ compared to $\mathrm{Ca}$ application. This may be owe to that the decline of acidity is attributed to increase in citric acid glyoxylase activity during ripening or reduction in acid content may be due to their conversion into sugars and further utilization in metabolic process during storage (Rathore et al., 2007). There were no significant effect between foliar application of $\mathrm{Ca}$ as $\mathrm{CaCl}_{2}$ and control treatment on TSS in tomato fruits (Rab and Haq, 2012), while control treatment reflected high organic acid \%, and low soluble sugar \% and V.C. content in tomato fruits compared to application of $\mathrm{Ca}$ as $\mathrm{CaCl}_{2}$ (Yang et al., 2012).

\section{Effect of application time:}

As regard to V.C. content, the data in Fig. 2 reveal that spraying tomato plants with $\mathrm{Ca}$ two times $\left(\mathrm{T}_{3}\right)$ recorded the highest value of V.C. content (19.2, 19.8) compared to spraying one time at flowering (17.1, 18.0) or one time after 15 days of flowering $(17.2,17.9)$ ) in the $1^{\text {st }}$ and $2^{\text {nd }}$ seasons, respectively. The same data (Table 8) reveal that $\mathrm{pH}$ at the initial of storage and the end of storage period did not significantly affect in both seasons as wll as TSS at the initial time in $2^{\text {nd }}$ season, but spraying plants once after 15 days of flowering or twice increased TSS in fruits at the end of storage period in the second season. In this connection Lewandowski (2003) found that spraying strawberry with $\mathrm{Ca}$ at petal fall stage or 5 days intervals from petal fall stage had no effect on TSS and TA. Bhattarai and Gautam (2006) found that there were no significant 


\section{El-Tantawy, E. M. and M.I. Mahmoud}

effect among different Ca concentration on $\mathrm{pH}$, TSS and TA $\%$ in tomato fruits during the storage period. On the other hand, Rubio et al., (2009) found that increasing Ca concentration decreased TSS in fruits. Regarding lycopene content, the same data reveal that spraying tomato plants with $\mathrm{Ca}$ at flowering increased the content of lycopene in both $1^{\text {st }}$ and $2^{\text {nd }}$ dates of storage periods without significant differences when compared with spraying two times at the end time of storage, while spraying one time after 15 days of flowering recorded the lowest values in this respect.

\section{Effect of interaction:}

Data in Fig. 3 and Table 9 show significant differences among the interaction treatments due to foliar application of $\mathrm{Ca}$ in different sources and its application times on tomato fryit quality in both seasons. As regard to the content of V.C., the data in Fig. 3 show that sparying tomato plant with $\mathrm{Ca}$ as $\mathrm{Ca}$ carbonate or Ca-chelate twice (at flowering + after 15 days of flowering) were the superior treatments which recorded the highest values for V.C. content in both seasons in comparison with the other interaction treatments. Regarding $\mathrm{pH}$, lycopene and TSS contents, the data in Table 9 illustrate that $\mathrm{pH}$ of tomato fruits at both the initial and the end of storage period were not significantly affected by such interaction treatments. In addition, the conteent of lycopen did not have a constant trend in the $1^{\text {st }}$ season which significantly increased at the initial time with spraying one time at flowering by
Ca-carbonate, but at the end of storage it significantly increased with Ca- chelate twice $\left(\mathrm{T}_{3}\right)$. On the other side, lycopen content had a constant trend in the $2^{\text {nd }}$ season. Application of $\mathrm{Ca}$ twice $\left(\mathrm{T}_{3}\right)$ without $\mathrm{Ca}$ or with $\mathrm{Ca}$ chelate recorded the highest lycopene content, while it recorded the lowest value, approximately when plants treated two times with Ca- carbonate. In this connection, Elbeik (2014) found that spraying tomato plants with $\mathrm{Ca}$ with regardless of sources $\left(\mathrm{CaCl}_{2}, \mathrm{Ca}\right.$-chelate $)$ at different time of application (every 5, 10 and 15 days) increased lycopene content in tomato fruits during storage compared to control. Concerning TSS, the data reveal that spraying of $\mathrm{Ca}$ as $\mathrm{Ca}$-carbonate twice or $\mathrm{Ca}$ chelate on time after 15 days of flowering in the $1^{\text {st }}$ season were the superior interaction treatments for increasing TSS in $1^{\text {st }}$ and $2^{\text {nd }}$ dates of storage periods, respectively.While, spraying with $\mathrm{Ca}$ as $\mathrm{Ca}$-chloride twice was the superior treatments in $2^{\text {nd }}$ season only. In this connection Lewandowski (2003) found that spraying with $\mathrm{CaCl}_{2}$ did not show any effect on TSS and TA in strawberry fruits. TSS $\%$ and $\mathrm{pH}$ at the end of storage period in tomato fruits were significantly increased with application of $\mathrm{CaCl}_{2}$. In this connection, control treatment or application of $\mathrm{Ca}$-chelate were the superior treatments for V.C. content at the end of storage period (Elbeik, 2014).

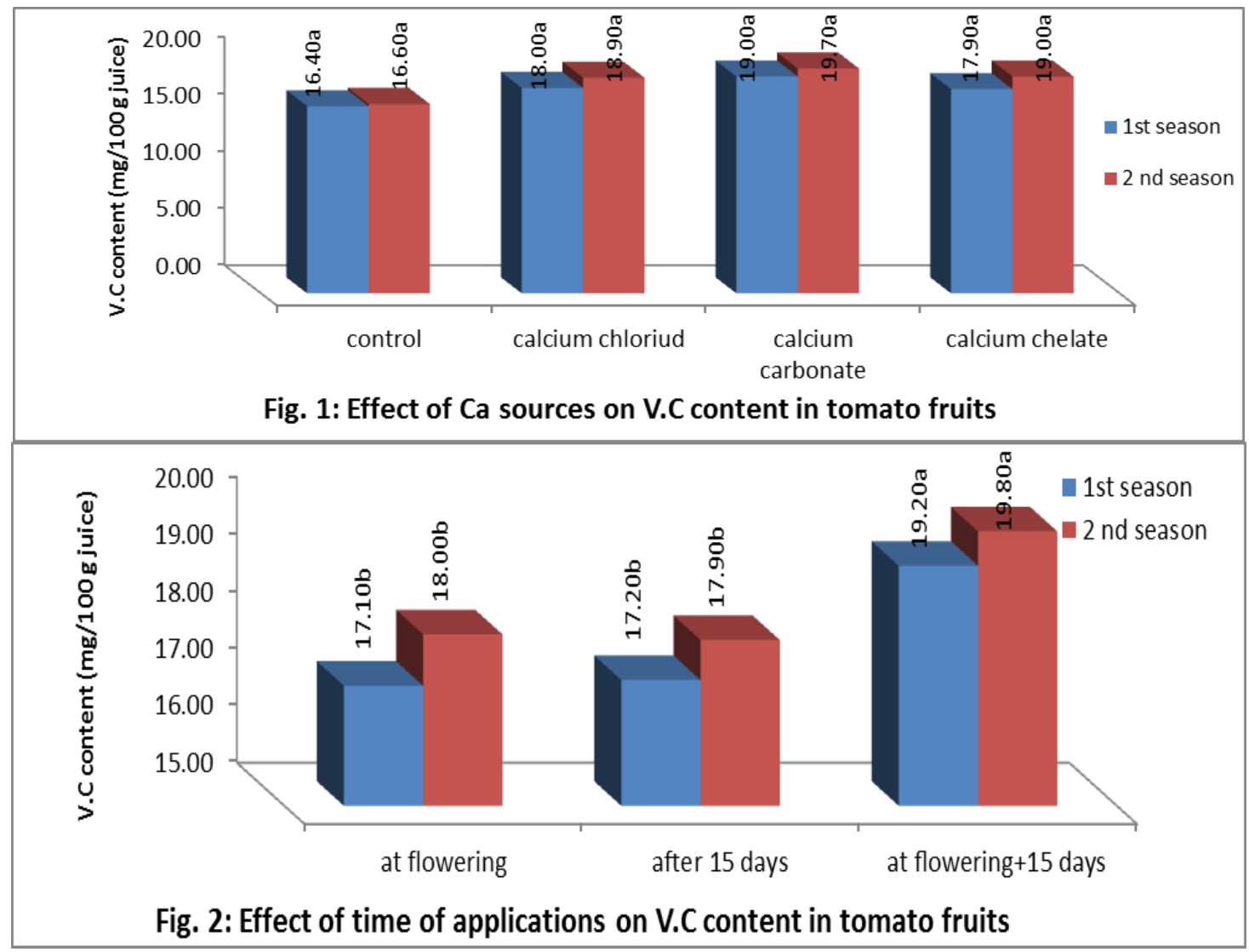




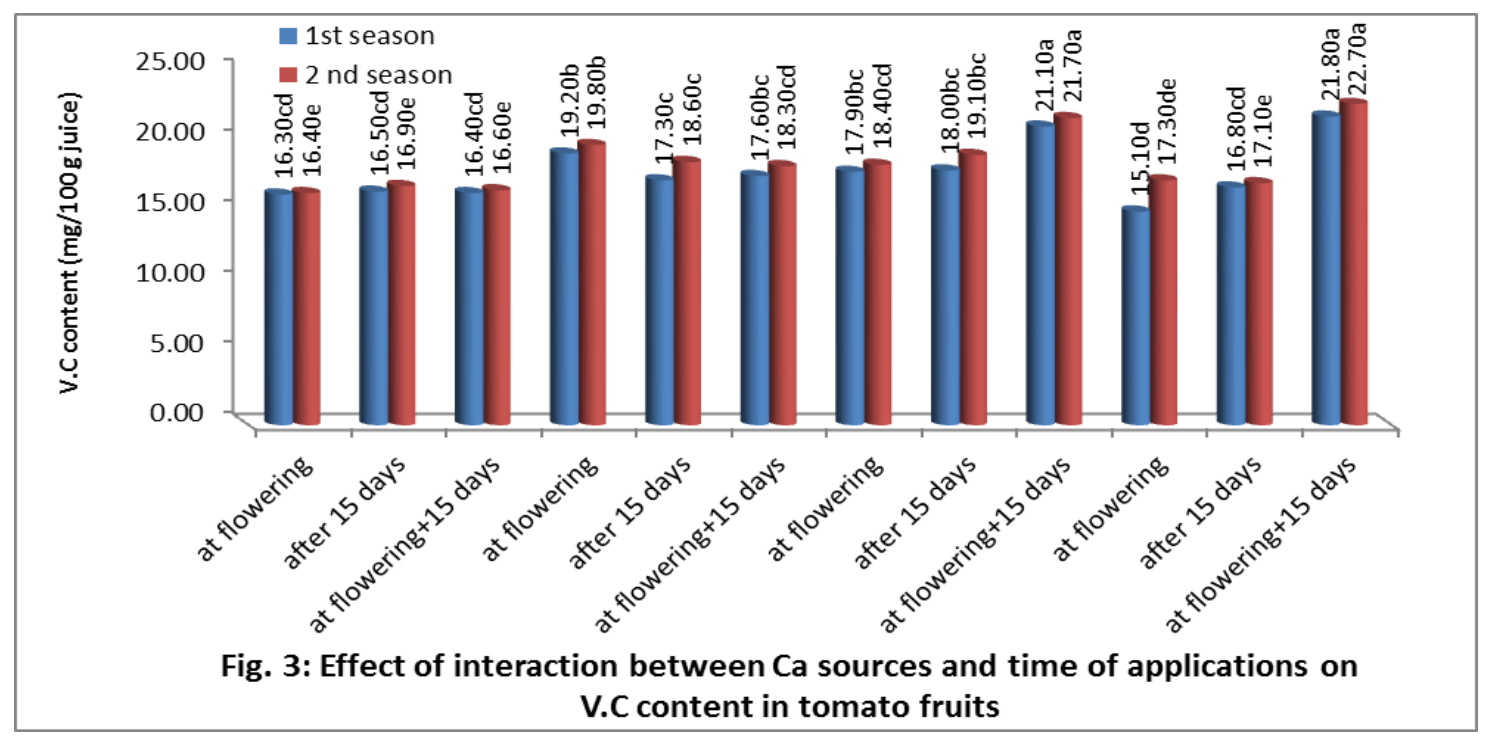

Table 8: Effect of calcium sources and its time of application on some fruit quality parameters of tomato during 2011/2012 and 2012/2013 seasons.

\begin{tabular}{|c|c|c|c|c|c|c|c|c|c|c|c|c|}
\hline $\begin{array}{l}\text { Parameters } \\
\text { eents }\end{array}$ & $\begin{array}{c}\text { pH } \\
\text { at } \\
\text { initial } \\
\text { time }\end{array}$ & $\begin{array}{c}\text { pH } \\
\text { after } \\
10 \text { days }\end{array}$ & $\begin{array}{l}\text { Lycopene } \\
\text { (mg/100gm } \\
\text { Juice) at the } \\
\text { initial time }\end{array}$ & $\begin{array}{c}\begin{array}{c}\text { Lycopene } \\
\text { (mg/100g }\end{array} \\
\text { Juice) } \\
\text { after } \\
\text { 10 days } \\
\end{array}$ & $\begin{array}{c}\text { T.S.S } \\
(\%) \\
\text { At initial } \\
\text { time } \\
\end{array}$ & $\begin{array}{l}\text { T.S.S } \\
\text { (\%)after } \\
10 \text { days }\end{array}$ & $\begin{array}{c}\text { pH } \\
\text { at } \\
\text { initial } \\
\text { time }\end{array}$ & $\begin{array}{c}\mathrm{pH} \\
\text { after } \\
10 \text { days }\end{array}$ & $\begin{array}{c}\text { Lycopene } \\
\text { (mg/100g } \\
\text { Juice) } \\
\text { at initial } \\
\text { time }\end{array}$ & $\begin{array}{c}\text { Lycopene } \\
(\mathrm{mg} / 100 \mathrm{~g} \\
\text { Juice) after } \\
10 \text { days }\end{array}$ & $\begin{array}{c}\text { T.S.S } \\
(\%) \\
\text { At initial } \\
\text { time }\end{array}$ & $\begin{array}{l}\text { T.S.S } \\
(\%) \text { after } \\
10 \text { days }\end{array}$ \\
\hline Calcium sources & \multicolumn{6}{|c|}{ First season } & \multicolumn{6}{|c|}{ Second season } \\
\hline Without calcium & $4.53 \mathrm{a}$ & $5.28 \mathrm{a}$ & $0.049 \mathrm{ab}$ & $0.099 \mathrm{a}$ & $7.81 \mathrm{a}$ & $9.67 \mathrm{a}$ & $4.72 \mathrm{a}$ & $5.13 \mathrm{a}$ & $0.075 \mathrm{a}$ & $0.108 \mathrm{a}$ & $7.48 \mathrm{~b}$ & $7.97 \mathrm{~b}$ \\
\hline Calcium chloride & $4.72 \mathrm{a}$ & $5.40 \mathrm{a}$ & $0.033 b$ & $0.043 \mathrm{c}$ & $8.08 \mathrm{a}$ & $9.08 \mathrm{a}$ & $5.08 \mathrm{a}$ & $5.38 \mathrm{a}$ & $0.045 \mathrm{c}$ & $0.074 \mathrm{c}$ & $8.45 \mathrm{ab}$ & $8.82 \mathrm{a}$ \\
\hline Calcium carbonate & $4.89 \mathrm{a}$ & $5.33 \mathrm{a}$ & $0.053 \mathrm{a}$ & $0.065 \mathrm{~b}$ & $7.57 \mathrm{a}$ & $9.28 \mathrm{a}$ & $5.22 \mathrm{a}$ & $5.43 \mathrm{a}$ & $0.064 b$ & $0.089 \mathrm{~b}$ & $8.43 \mathrm{ab}$ & $8.71 \mathrm{a}$ \\
\hline Calcium chelate & $4.88 \mathrm{a}$ & $5.20 \mathrm{a}$ & $0.052 \mathrm{a}$ & $0.090 \mathrm{a}$ & $7.60 \mathrm{a}$ & $9.98 \mathrm{a}$ & $5.18 \mathrm{a}$ & $5.33 \mathrm{a}$ & $0.067 \mathrm{ab}$ & $0.096 \mathrm{ab}$ & $8.49 \mathrm{a}$ & $8.94 \mathrm{a}$ \\
\hline Time of application & \multicolumn{6}{|c|}{ First season } & \multicolumn{6}{|c|}{ Second season } \\
\hline $\mathrm{T} 1$ (at flowering) & $4.60 \mathrm{a}$ & $5.26 \mathrm{a}$ & $0.060 \mathrm{a}$ & $0.093 \mathrm{a}$ & $7.44 \mathrm{a}$ & $8.96 \mathrm{a}$ & $4.92 \mathrm{a}$ & $5.22 \mathrm{a}$ & $0.079 \mathrm{a}$ & $0.108 \mathrm{a}$ & $7.71 \mathrm{a}$ & $8.19 b$ \\
\hline $\mathrm{T} 2$ (after 15 days) & $4.84 \mathrm{a}$ & $5.40 \mathrm{a}$ & $0.038 b$ & $0.054 \mathrm{~b}$ & $7.85 \mathrm{a}$ & $9.72 \mathrm{a}$ & $5.10 \mathrm{a}$ & $5.33 \mathrm{a}$ & $0.047 \mathrm{c}$ & $0.072 b$ & $8.33 \mathrm{a}$ & $8.66 a$ \\
\hline $\begin{array}{l}\text { T3 (at flowering + } \\
15 \text { days) }\end{array}$ & $4.83 \mathrm{a}$ & $5.25 \mathrm{a}$ & $0.042 b$ & $0.076 \mathrm{a}$ & $8.02 \mathrm{a}$ & $9.83 \mathrm{a}$ & $5.13 \mathrm{a}$ & $5.40 \mathrm{a}$ & $0.063 b$ & $0.096 \mathrm{a}$ & $8.61 \mathrm{a}$ & $8.97 \mathrm{a}$ \\
\hline
\end{tabular}

*Values having the same alphabetical letter (s) did not significantly differ at 0.05 level of significance according to Duncan's multiple range test.

Table 9: Effect of interaction between calcium sources and its time of application on some fruit quality parameters of tomato during 2011/2012 and 2012/2013 seasons.

\begin{tabular}{|c|c|c|c|c|c|c|c|c|c|c|c|c|c|}
\hline Treatments & Parameters & $\begin{array}{l}\mathrm{pH} \\
\text { at initial } \\
\text { time }\end{array}$ & $\begin{array}{c}\mathrm{pH} \\
1 \text { after } \\
10 \text { ays }\end{array}$ & $\begin{array}{c}\text { Lycopene } \\
(\mathrm{mg} / 100 \mathrm{gm}( \\
\text { Juice) at } \\
\text { initial } \\
\text { time }\end{array}$ & $\begin{array}{c}\text { Lycopene } \\
\text { (mg/100gm } \\
\text { Juice) } \\
\text { after } \\
10 \text { days } \\
\end{array}$ & $\begin{array}{c}\text { T.S.S } \\
(\%) \text { at } \\
\text { initial } \\
\text { time }\end{array}$ & $\begin{array}{c}\text { T.S.S } \\
(\%) \\
\text { after } \\
10 \text { days }\end{array}$ & $\begin{array}{c}\mathbf{p H} \\
\text { at initial } \\
\text { time }\end{array}$ & $\begin{array}{c}\text { pH } \\
\text { after } \\
10 \text { days }\end{array}$ & $\begin{array}{c}\text { Lycopene } \\
\text { (mg/100gm } \\
\text { Juice) at } \\
\text { initial time }\end{array}$ & $\begin{array}{c}\text { Lycopene } \\
\text { (mg/100gm } \\
\text { Juice) } \\
\text { after } \\
10 \text { days }\end{array}$ & $\begin{array}{c}\text { T.S.S } \\
(\%) \text { at } \\
\text { initial } \\
\text { time }\end{array}$ & $\begin{array}{c}\text { T.S.S } \\
(\%) \\
\text { after } \\
10 \text { days }\end{array}$ \\
\hline \multirow{2}{*}{$\begin{array}{l}\text { Calcium } \\
\text { sources }\end{array}$} & $\begin{array}{c}\text { Time of } \\
\text { application }\end{array}$ & \multicolumn{6}{|c|}{ First season } & \multicolumn{6}{|c|}{ Second season } \\
\hline & At flowering & $4.53 \mathrm{a}$ & $5.33 \mathrm{a}$ & $0.067 \mathrm{ab}$ & $0.101 b$ & $7.81 \mathrm{ab}$ & $9.50 \mathrm{abc}$ & $4.69 b$ & $5.03 \mathrm{a}$ & $0.084 \mathrm{ab}$ & $0.113 b$ & $7.40 \mathrm{~d}$ & $7.86 \mathrm{e}$ \\
\hline \multirow{3}{*}{$\begin{array}{l}\text { Without } \\
\text { calcium }\end{array}$} & After 15 days & $4 . .50 \mathrm{a}$ & $5.29 \mathrm{a}$ & $0.031 \mathrm{e}$ & $0.053 \mathrm{de}$ & 7.63ab & $9.52 \mathrm{abc}$ & $4.71 b$ & $5.10 \mathrm{a}$ & $0.043 \mathrm{~cd}$ & $0.069 \mathrm{~d}$ & $7.55 \mathrm{~cd}$ & $7.90 \mathrm{e}$ \\
\hline & $\begin{array}{c}\text { At flowering+15 } \\
\text { days }\end{array}$ & $4.56 \mathrm{a}$ & $5.22 \mathrm{a}$ & $0.048 b-e$ & $0.145 \mathrm{a}$ & $8.00 \mathrm{ab}$ & $10.00 \mathrm{ab}$ & $4.75 b$ & $5.25 \mathrm{a}$ & $0.097 \mathrm{a}$ & $0.141 \mathrm{a}$ & $7.50 \mathrm{~cd}$ & $8.13 \mathrm{de}$ \\
\hline & At flowering & $4.21 \mathrm{a}$ & $5.33 \mathrm{a}$ & $0.033 \mathrm{de}$ & $0.043 \mathrm{de}$ & $6.75 b$ & $9.00 \mathrm{bc}$ & $4.65 b$ & $5.13 \mathrm{a}$ & $0.051 \mathrm{~cd}$ & $0.076 \mathrm{~cd}$ & $7.25 \mathrm{~d}$ & $8.04 \mathrm{de}$ \\
\hline \multirow{3}{*}{$\begin{array}{l}\text { Calcium } \\
\text { chloride }\end{array}$} & After 15 days & $4.96 \mathrm{a}$ & $5.61 \mathrm{a}$ & $0.034 \mathrm{de}$ & $0.045 \mathrm{de}$ & $8.50 \mathrm{ab}$ & $9.17 b c$ & $5.27 \mathrm{a}$ & $5.42 \mathrm{a}$ & $0.048 \mathrm{~cd}$ & $0.076 \mathrm{~cd}$ & $8.50 \mathrm{bc}$ & $8.75 \mathrm{bcd}$ \\
\hline & $\begin{array}{c}\text { At flowering+15 } \\
\text { days }\end{array}$ & $4.99 \mathrm{a}$ & $5.24 \mathrm{a}$ & $0.032 \mathrm{de}$ & $0.041 \mathrm{e}$ & $9.00 \mathrm{a}$ & $9.08 \mathrm{bc}$ & $5.32 \mathrm{a}$ & $5.56 \mathrm{a}$ & $0.037 \mathrm{~d}$ & $0.069 \mathrm{~d}$ & $9.58 \mathrm{a}$ & $9.65 \mathrm{a}$ \\
\hline & At flowering & $4.79 \mathrm{a}$ & $5.24 \mathrm{a}$ & $0.075 \mathrm{a}$ & $0.093 \mathrm{~b}$ & $6.75 b$ & $8.42 \mathrm{c}$ & $5.20 \mathrm{a}$ & $5.45 \mathrm{a}$ & $0.080 \mathrm{~b}$ & $0.104 b c \quad \&$ & $8.00 \mathrm{bcd}$ & $8.36 \mathrm{cde}$ \\
\hline \multirow{3}{*}{$\begin{array}{l}\text { Calcium } \\
\text { carbonate }\end{array}$} & After 15 days & $4.96 \mathrm{a}$ & $5.43 a$ & $0.051 \mathrm{bcd}$ & $0.057 \mathrm{cde}$ & 7.99ab & $9.33 \mathrm{bc}$ & $5.23 \mathrm{a}$ & $5.42 \mathrm{a}$ & $0.053 \mathrm{~cd}$ & $0.074 \mathrm{~cd}$ & $8.75 \mathrm{ab}$ & $9.00 \mathrm{abc}$ \\
\hline & $\begin{array}{c}\text { At flowering }+15 \\
\text { days }\end{array}$ & $4.92 \mathrm{a}$ & $5.32 \mathrm{a}$ & $0.032 \mathrm{de}$ & $0.045 \mathrm{de}$ & 7.98ab & $10.08 \mathrm{ab}$ & $5.24 \mathrm{a}$ & $5.40 \mathrm{a}$ & $0.060 \mathrm{c}$ & $0.088 \mathrm{c}$ & $8.52 b c$ & $8.75 \mathrm{bcd}$ \\
\hline & At flowering & $4.86 a$ & $5.14 \mathrm{a}$ & $0.066 \mathrm{ab}$ & $0.134 \mathrm{a}$ & $8.45 \mathrm{ab}$ & $8.92 b c$ & $5.13 \mathrm{a}$ & $5.27 \mathrm{a}$ & $0.100 \mathrm{a}$ & $0.137 \mathrm{a}$ & $8.12 \mathrm{bcd}$ & $8.50 \mathrm{cde}$ \\
\hline \multirow{2}{*}{$\begin{array}{l}\text { Calcium } \\
\text { chelate }\end{array}$} & After 15 days & $4.94 \mathrm{a}$ & $5.27 \mathrm{a}$ & $0.037 \mathrm{cde}$ & $0.062 \mathrm{~cd}$ & $7.26 \mathrm{ab}$ & $10.85 \mathrm{a}$ & $5.19 \mathrm{a}$ & $5.34 \mathrm{a}$ & $0.043 \mathrm{~cd}$ & $0.069 \mathrm{~d}$ & $8.43 b c$ & $9.00 \mathrm{abc}$ \\
\hline & $\begin{array}{c}\text { At nowering+15 } \\
\text { days }\end{array}$ & $4.85 \mathrm{a}$ & $5.20 \mathrm{a}$ & $0.054 \mathrm{bc}$ & $0.073 \mathrm{c}$ & $7.08 \mathrm{~b}$ & 10.17ab & $5.21 \mathrm{a}$ & $5.38 \mathrm{a}$ & $0.059 \mathrm{c}$ & $0.084 \mathrm{c}$ & $8.72 \mathrm{ab}$ & $9.33 \mathrm{ab}$ \\
\hline
\end{tabular}




\section{CONCLUSION}

Spraying tomato plants grown under low tunnels in calcareous soil with $\mathrm{Ca}$ in different sources had positive effects on both marketable yield and blossomend rot incidence, total yield, marketability $\%$ and BER\%. But it had slight effect on fruit quality after 10 days of storage period compared to control. Application times of Ca did not gave significant effect, almost on all the previous determined parameters.

\section{REFERENCES}

Aghofack-Nguemezi, J. and V. Tatchago (2010). Effects of fertilizers containing calcium and/or magnesium on the growth, development of plants and the quality of tomato fruits in the western highlands of cameroon. International J. of Agric. Res., 5: 821-831.

Aghofack-Nguemezi, J., G. T. Noumbo and C. N. Nkumbe (2014). Influence of calcium and magnesium based fertilizers on fungal diseases, plant growth parameters and fruit quality of three varieties of tomato (Solanum lycopersicum). J. of Sci. and Techn., 34 (1): 9-20.

A.O.A.C. (1975). Association of Official Agricultural Chemist. Methods of Analysis. $12^{\text {th }}$ ed. A.O.A.C. Washington D.C. USA.

Barber, N. J. and J. Barber. 2002. Lycopene and prostate. Prostate Cancer and Prostatic Disease, 5: 6-12.

Bhattarai, D.R. and D. M. Gautam (2006). Effect of harvesting method and calcium on post harvest physiology of tomato. Nepal Agric. Res. J. 7: $37-$ 41.

Bradfield, E.G. and C.G. Guttridge (1984). Effects of night-time humidity and nutrient solution concentration on the calcium content of tomato fruit. Sci. Hort. 22:207-374.

Brady, C. J. (1987). Fruit ripening. Annual Review of Plant physiology, 38: 155-178.

Byeon, S., S. Seo and J. Chung (2012). Relationships between blossom-end rot in pepper and calcium fertilization during the first fruit setting period. Korean J. Soil Sci. Fert. 45 (1): 79-82 .

Carpita, N. and M. C. McCann (2000). The Cell Wall. In: Biochemistry and Molecular Biology of Plants, Buchanan, B. and M. D. Rockville (ed.). Am. Soc. Plant Physiologists, UK., pp: 52-108.

Casado-Vela, J. S. S.and R.B. Martinez (2005). Proteomic approach to blossom-end rot in tomato fruits (Lycopersicon esculentum Mill.): antioxidant enzymes and the pen-tose phosphate pathway. Proteomics, 5: 2488-2496.

Chen, S., L. Wei and Y. Fang (2006). Effect of $\mathrm{CaCl}_{2}$ treatment on the physiological qualities of postharvest tomato. Acta Agriculturae BorealiOccidentalis Sinica, 15 (1): 156-159.
De Freitas, S.T., and E.J. Mitcham (2012). Factors involved in fruit calcium deficiency disorders. Hortic. Rev., 40: 107-146.

Duncan, D.B. (1958). Multiple rang and multiple F test. Biometrics, 11: 1-42.

Del-Amor, F.K., and L.F.M. Marcelis (2003). Regulation of nutrient uptake, water uptake and growth under calcium starvation and recovery. J. Hort. Sci. Biotechnol., 78: 343-349.

Elbeik, A. K.M. (2014). Effect of calcium spray on growth, yield, blossom-end rot occurrence and storability of tomatoes under calcareous soil conditions in delta of El-Arish Valley. Zagazig J. Agric. Res., 41 (2) : 257-271.

Giovannoni, J. (2001). Molecular biology of fruit maturation and ripening. Annual Review of Plant Physiology and Plant Molecular Biology 52: 725-749.

Goodwin, P.B. (1978). Phytohormones and fruit growth. In: Letham, D.S., P.B. Goodwin, and T.J.Y. Higgins, (Eds.), Phytohormones and Related Compounds-A Comprehensive Treatise. Elsevier, Amsterdam, pp. 175-214.

Hao, X. and A.P. Papadopoulos (2004). Effect of calcium and magnesium on plant growth, biomass partitioning, and fruit yield of winter greenhouse tomato.HortScience, 39 (3): 512-515.

Ho, L.C. (1989). Environmental effects on the diurnal accumulation of $\mathrm{Ca}$ by young fruit and leaves of tomato plants. Ann. Bot., 63: 282-288.

Ho, L.C. and P.J. White (2005). A cellular hypothesis for the induction of blossom-end rot. Ann. Bot., 95:571-581.

Ilyas, M., G. Ayub, and Z. Hussain (2014). Response of tomato to different levels of calcium and magnesium concentration. World Applied Sci. J., 31 (9): 1560-1564.

Imas, P. (2000). Integrated nutrient management for sustaining crop yields in calcareous soils. National Symposium on: Balanced nutrition of groundnut and other field crops grown in calcareous soils of India, September 19-22, Junagadh, Gujarat, INDIA.

Inaba, M. and P.G. Crandall (1986). Cold-shock treatment of mature green tomatoes to delay colour development and increase shelf-life during room temperature storage. Proceedings of Florida State Hort. Soci., 99: 143- 145.

Khan, M. M. A., C. Gautam, F. Mohammad, M. H. Siddiqui, M. Naeem and M. N. Khan (2006). Effect of gibberellic acid spray on performance of tomato. Turk. J. Biol., 30: 11-16.

Leshem, Y. Y. (1991). Plant Membrane Senescence. In: Penel, C. and Greppin, H. (Editors). Plant signaling, plasma membrane and change of state. University of Geneva Press, Geneva.

Lester,G. E. and Grusak, M. A. (2004). Field application of chelated calcium: postharvest effects on cantaloupe and honey dew fruit quality. HortTechnology, 14 (1): 29-38. 
Lewandowski, M. (2003). Effect of Calcium and Boron Sprays on Yield and Quality of "Elsanta" Strawberry. J. Plant Nutr., 26(3): 671-682.

Magee, R. I., F. Caporaso and A. Prakash (2003). Effects of exogenous calcium salt treatments on inhibiting irradiation-induced softening in diced Roma tomatoes. J. of Food Sci., 68(8): 24302435.

Marcelis, L.F.M. and L.C. Ho (1999). Blossom-end rot in relation to growth rate and calcium content in fruits of sweet pepper (Capsicum annuum L.). J. Exp. Bot., 50:357-363.

Marschner, H. (1986). Mineral nutrition of higher plants. Academic Press, New York, USA.

Marschner, H. (1993). Functions of mineral nutrients: Macronutrients. In: Marschner, H. (ed) Mineral Nutrition of Higher Plants. $2^{\text {nd }}$ ed, pp 229-299.

Mengel, K. and E. Kirkby (1978). Principles of Plant Nutrition. $1^{\text {st }}$ ed., International Potash Institute, Worblaufen - Bern, Switzerland.

Mengel, K. and E. Kirkby (2001). Principles of Plant Nutrition. $5^{\text {th }}$ ed., International Potash Institute, Bern, Switzerland.

Mestre,T. C. F. Garcia-Sanchez, F. Rubio, V. Martinez and R. M. Rivero (2012). Glutathione homeostasis as an important and novel factor controlling blossom-end rot development in calcium-deficient tomato fruits. J. of Plant Physiology, $169: 1719-1727$.

Nonami, H., T. Fukuyama, M. Yamamoto, L. Yang and Y. Hashimoto (1995). Blossom-End Rot of tomato plants may not be directly caused by calcium deficiency. Acta Hort., 396: 107-114.

Pila, N., N.B.Gol, and T.V. Rao (2010). Effect of post harvest treatments on physicochemical characteristics and shelf life of tomato (Lycopersicon esculentum Mill.) fruits during storage. American-Eurasian J. Agric. and Environ. Sci., 9(5): 470-479.

Rab, A.,and I. Haq (2012). Foliar application of calcium chloride and borax influences plant growth, yield, and quality of tomato (Lycopersicon esculentum Mill.) fruit. Turk. J. Agric., 36 : 695-701.

Ranganna, S. (1979). Manual of analysis of fruit and vegetable products. Tata Mc Craw-Hill publishing company limited, New Delhi. pp. 173.

Rathore, H.A., T. Masud, S. Sammi and A.H. Soomro (2007). Effect of storage on physico-chemical composition and sensory properties of Mango (Mangifera indica L.) variety Dosehari. Pakistan J. Nutrition, 6(2): 143-148.

Rubio, J.S., F. Garcia-Sanchez, F. Rubio, and V. Martınez (2009). Yield, blossom-end rot incidence, and fruit quality in pepper plants under moderate salinity are affected by $\mathrm{K}^{+}$and $\mathrm{Ca}^{2+}$ fertilization. Scientia Horticulturae, 119 : 79-87.
Sams, C.E., W.S. Conway, J.A. Abbott, R.J. Lewis and N. Ben Shalom (1993). Firmness and decay of apples following postharvest pressure infiltration of calcium and heat treatment. J. of Amer. Soci. of Hort. Sci., 118: 623-627.

Saure, M. C. (2014). Why calcium deficiency is not the causeof blossom-end rot in tomato and pepper fruit - a reapprisal. Scientia Horticulturae, 174: 154-154.

Schmitz- Eiberger, M., R. Haefs and G. Noga (2002). Calcium deficiency - influence on the antioxidative defense system in tomato plants. J. Plant Physiol., 159: 733-742.

Senevirathna, P. A. W. A. N. K and W. A. M. Daundasekera (2010). Effect of postharvest calcium chloride vacuum infiltration on the shelf life and quality of tomato ( $c v$. 'thilina'). Cey. J. Sci. (Bio. Sci.), 39 (1): 35-44.

Setha, S. (2012). Roles of abscissic acid in fruit ripening. Walailak J. Sci. Technol., 9 (4): 297- 308.

Sharma, R.M., R. Yamdagni, H. Gaur and R.K. Shukla (1996). Role of calcium in horticulture - A review. Haryana J. Hort.Sci., 25 (4): 205.

Smit, J.N., and N.J.J. Combrink (2005). Pollination and yield of winter-grown greenhouse tomatoes as affected by boron nutrition, cluster vibration and relative humidity. South Afr. J. Plant Soil, 22: 110-115.

Snedecor, G.W. and W.G. Cochran (1980). Statistical Methods 7th ed. Iowa State Univ., Press. Ames. Iowa, USA.

Srivastava, P.C. and U.C. Gupta (1996). Trace Elements In Crop Production. Sci. Publisher Inc., 355 Pp.

Tuna, A.L., C. Kaya, M. Ashraf, H. Altunlu, I. Yokas and B. Yagmur (2007). The effect of calcium sulphate on growth membrane stability and nutrient uptake of tomato plants grown under stress. Environmental Experimental Botany, 9: 173-178.

Usten, N.H., A.L., Yokas and H. Saygili (2006). Influence of potassium and calcium level on severity of tomato pith necrosis and yield of greenhouse tomatoes. ISHS Acta Hortic, 808: 345-350.

Waterland, N. L., C. A. Campbell, J. J. Finer and M. L. Jones (2010). Abscissic acid application enhances drought stress tolerance in

bedding plants. HortScience, 45(3): 409- 413.

Yang, L., H. Qua, Y. Zhanga and F. Li (2012). Effects of partial root-zone irrigation on physiology, fruit yield and quality and water use efficiency of tomato under different calcium levels. Agricultural Water Management, 104: 89- 94.

Zook, M. N., J. S. Rush and J. C. Kuc (1987). A role for $\mathrm{Ca}^{2+}$ in the elicitation of rishitin and lubimin accumulation in potato tuber tissue. Plant Physiology, 84: 520-525. 
تأثير مصـادر ومواعيد اضـافه الكالسيوم على المحصول القابل للتسويق والإصـابة بعفن الطرف الزهري وجوده

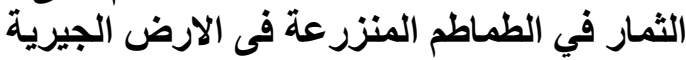

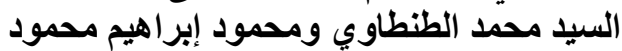

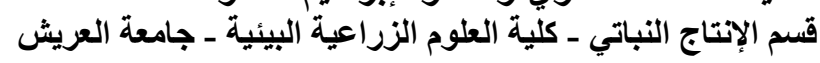

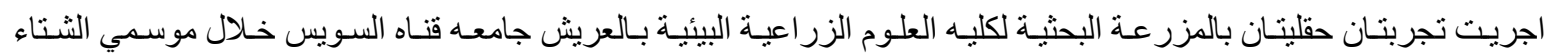

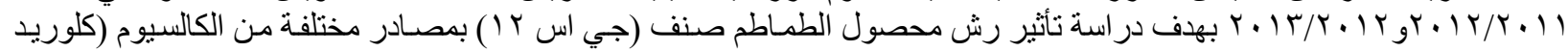

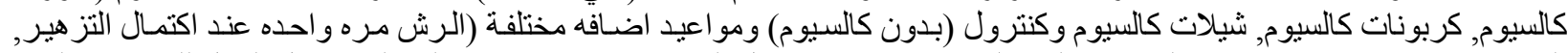

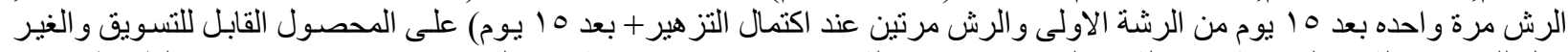

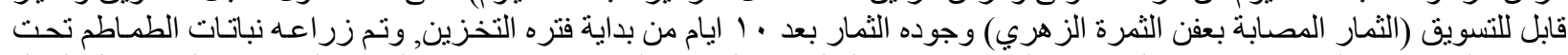

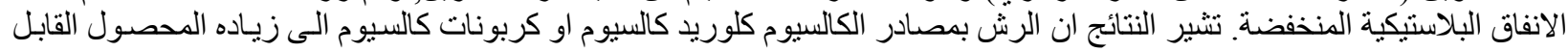

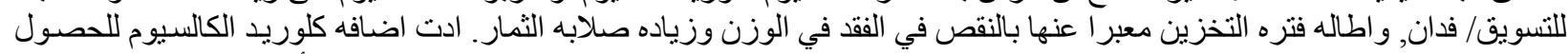

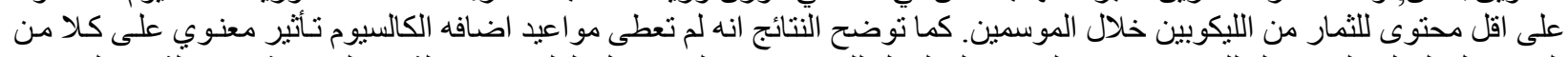

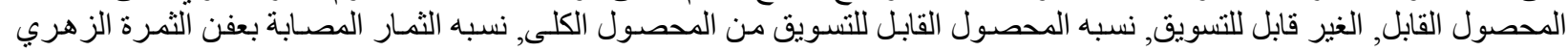

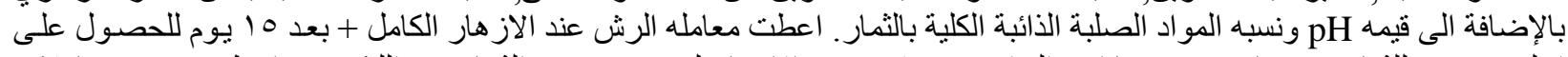

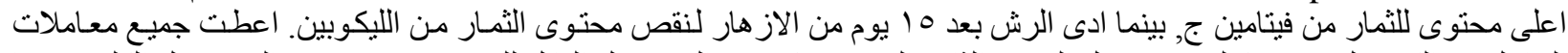

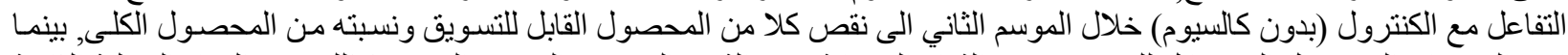

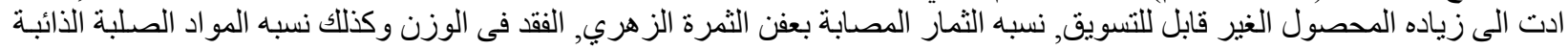

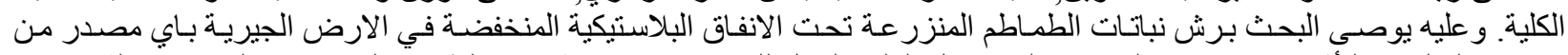

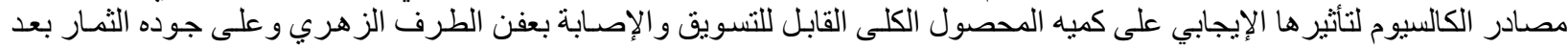
عشره ايام من التخزين مقارنه بالكنترول. 